\title{
Biyoçeşitlilik İndisleri Kullanılarak Öncelikli Koruma Alanı Seçimine Bir Örnek: Kargı Çayı ve Karpuz Çayı Vadileri (Akdeniz Bölgesi-Türkiye)
}

\author{
Primary Conservation Area Selection with Biodiversity Indices: A Case Study on the Kargi \\ and Karpuz River Valleys (Mediterranean Region-Turkey)
}

\author{
Seda AKKURT GÜMÜȘ ${ }^{1} \oplus$, Meral AVCI ${ }^{2} \odot$
}

${ }^{1}$ Manisa Celal Bayar Üniversitesi, Coğrafi Bilgi Sistemleri Programı, Manisa, Türkiye

${ }^{2}$ İstanbul Üniversitesi, Coğrafya Bölümü, İstanbul, Türkiye

ORCID: S.A.G. 0000-0001-7879-8460; M.A. 0000-0003-4367-3021

\section{öz}

Biyoçeşitlilik kavramı ilk ortaya çıktığından beri çeşitli yaklaşım ve metotlarla açıklanmaya çalışılmıştır. Türkiye'de bitki tür çeşitliliği ve endemizm oranının yüksek olduğu belirli alanlarda biyoçeşitliliğin korunması ve sürdürülebilir bir şekilde yönetilmesi oldukça önemlidir. Biyoçeşitliliğin farklı ölçeklerde belirlenmesi, korumaya yönelik tedbirler alınmadan önce atılacak en önemli adımlardan birisidir. Özellikle Akdeniz Bölgesi'nde bitki türleri birçok farklı etmen sebebiyle tehlike altındadır. Bu tehditler karşısında tür çeşitliliğinin daha zengin olduğu alanlara odaklanıp koruma önceliğinin bu bölgelere verilmesi faydalı bir girişim olacaktır. Bu çalışmada Akdeniz Bölgesi'nde iki akarsu vadisinde (Kargı Çayı vadisi ve Karpuz Çayı vadisi) aynı fenolojik dönemde yapılan arazi çalışmalarıyla toplanan veri kullanılarak, bitki tür çeşitliliği alfa $(\boldsymbol{\alpha})$ ve beta $(\boldsymbol{\beta})$ biyoçeşitlilik indisleriyle hesaplanmıştır. Alfa tür çeşitliliği için ShannonWiener indisi $(\boldsymbol{a H})$, beta çeşitlilik için ise Whittaker'ın beta çeşitlilik $(\boldsymbol{\beta} \boldsymbol{w})$ indisi kullanılmıştır. Karpuz Çayı'nda alfa çeşitliliğin en az olduğu alanlar akarsuyun kaynak çevresi ve üst çığııı, en fazla olduğu alanlar alt ve orta çığırdır. Beta çeşitlilik ise üst çığırda yüksek, antropojenik faaliyetlerin hakim olduğu alt ve orta kesimlerde düşüktür. Kargı Çayı'nda alfa ve beta çeşitlilik orta kesimde az, yukarı ve aşağı çığırlarda fazladır. İki vadinin bitki çeşitliliği Whittaker'ın gama çeşitlilik $(\boldsymbol{\gamma})$ indisi kullanılarak karşılaştırılmış ve Kargı Çayı vadisi korumada öncelikli alan olarak belirlenmiştir.

Anahtar kelimeler: Alfa, beta ve gama çeşitlilik indisi, Anadolu, bitki çeşitliliği

\section{ABSTRACT}

Diversity components are explained with different concepts, approaches, and methods. Biodiversity conservation in specific areas of rich plant species diversity and endemism rate in Turkey is significant enough to be managed sustainably. Identifying biodiversity at different scales is one of the most critical steps before implementing protection measures. In the Mediterranean region, plant species are in danger due to various factors: expansion of urban areas, rapid population growth, and fire. Against these threats, it will be a useful initiative to focus on areas with diverse species and to give priority to conservation in these regions. In this study, plant species diversity was calculated with the alpha $(\boldsymbol{\alpha})$ and beta $(\boldsymbol{\beta})$ biodiversity indices, using data collected from fieldwork in the two river valleys, Kargı and Karpuz. The Shannon-Wiener index $(\boldsymbol{a H})$ was used for alpha species diversity, and Whittaker's index ( $\boldsymbol{\beta} \boldsymbol{w})$ was preferred for the beta diversity index. As a result, the areas with the least alpha diversity in the Karpuz River valley are the source and the upper course of the river and the areas with the highest diversity are the lower and middle courses. Beta diversity is high in the upper course and less in the lower and middle courses where anthropogenic activities are dominant. In contrast, in the Kargı River valley, alpha and beta diversity is low in the middle part and more in the upper and lower courses. For all plant species diversity of the two valleys, Whittaker's gamma diversity index ( $\boldsymbol{\gamma}$ ) was used and the Kargı River valley was identified as the priority area for conservation.

Keywords: Alpha, beta and gamma diversity indices, Anatolia, plant diversity

Başvuru/Submitted: 02.07.2020 • Revizyon Talebi/Revision Requested: 17.08.2020 • Son Revizyon/Last Revision Received: 04.09.2020 • Kabul/Accepted: 30.09 .2020 - Online Yayın/Published Online: 22.12 .2020

Sorumlu yazar/Corresponding author: Seda AKKURT GÜMÜŞ / sedaakkurtgumus@gmail.com

Atıf/Citation: Akkurt Gumus, S., \& Avci, M. (2020). Primary conservation area sselection with biodiversity indices: A case study on the Kargı and Karpuz River Valleys (Mediterranean Region-Turkey). Cografya Dergisi, 41, 147-164. https://doi.org/10.26650/JGEOG2020-0056 


\section{EXTENDED ABSTRACT}

Biodiversity models are mostly used in the identification of areas where the species show high variation, i.e., richness, to determine the priority areas in conservation plans. The method selection and size of the study area is selected according to the purpose of the study to be performed.

The process of inventory creation, which forms the basis of biodiversity calculations, requires many preliminary studies such as limiting the study area, selecting sample areas, and determining the plants to be included in the diversity. In this study, the two river valleys were compared in terms of the plant species richness to discover the area that should initially be protected in the conservation plans. The sampled valleys were Karg1 and Karpuz, where the streams take their resources from the south of the Central Taurus Mountains and drain their waters into the Mediterranean Sea. The Karg1 River valley, which has 26 nationally rare species taxa and has no official protection status, faces the threat of tourism and urbanization. The river is in the region defined as the Toros Mountains Plant Diversity Center (SWA No. 15). The Karpuz River valley surrounded by large settlements such as Manavgat is also at risk for the same reasons. The Karpuz River valley also has no official protection status.

In this study, the Shannon-Wiener indice $(\boldsymbol{\alpha H})$ was used to define alpha $(\boldsymbol{\alpha})$ diversity, Whittaker's beta diversity indice $(\boldsymbol{\beta} \boldsymbol{w})$ was used for beta $(\boldsymbol{\beta})$ diversity, and Whittaker's gamma diversity $(\gamma)$ index was used for gamma diversity. With fieldwork conducted in the same phenological period in the two river valleys, the rates of the coverage area and habitat characteristics of each plant layer (herbaceous, shrub, and woody plant species) in the sample areas were recorded and coded. Before the field study, valleys were divided into $10 \times 10 \mathrm{~m}^{2}$ grids by Fishnet in the GIS environment. Sample area determination was used only as a reference; main sampling sites were created in places with high plant species diversity and abundance, with observations in fieldwork. A total of 175 different plant species were identified in 160 sample areas (80 each in the per valley), and the density ratio of each species was recorded.

The high alpha diversity areas in the Karpuz River were ÖA3A, ÖA5B, ÖA14A, ÖA1A, and ÖA8A; low alpha plant diversity was determined in the sample areas of ÖA7B, ÖA11D, ÖA10D, ÖA19D, and ÖA20C. All the sample areas with low diversity were relatively close to the settlements. High beta diversity values were calculated in ÖA14, ÖA3, Ö6, Ö18, and ÖA11. Low beta diversity values were calculated in ÖA2 and ÖA9, ÖA13, ÖA10, and ÖA12. ÖA2, which was one of the sample areas with low beta diversity, is in the middle of the stream bed and forest area with low coverage. The beta value is associated with the distance or proximity to human activities along with the natural ecological conditions. In the Karpuz River valley, nearby sample areas such as Hacioba, Uzunlar, and Gençler had low diversity values. High beta values were identified in the sample areas surrounded by Pinus brutia forests in the central part of the valley, Ahmetler, and north Güçlüköy.

The high alpha diversity values in Karg1 River were ÖA18 and ÖA20A, ÖA8A, ÖA9A, and ÖA11A. The low alpha diversity values were in ÖA17C, ÖA15C, ÖA1D, Ö17B, and ÖA17D. The areas with low value are in the middle of the stream bed near the Dereköy settlement, where the grazing and livestock activities have gained intensity. In Karg1 River, beta diversity was high in ÖA8, ÖA3, ÖA4, ÖA10, and ÖA20; it was low in ÖA13 and ÖA15, ÖA17, and ÖA16. Almost all the areas with reduced diversity coincide with the middle of the river valley.

In the areas close to the source and the estuary of the Karg1 River valley, plant diversity was high. The slope is quite steep in the middle part of the stream, making it difficult for plant growth. There are dense Pinus brutia forests in relatively flat areas with deep soils. The forest cover of coniferous species is weaker in species diversity. Another reason is that different types of plants can settle in larger areas where the riverbed width is relatively increased. According to the gamma results, which are evaluated by considering the whole valleys, the Kargı River valley has more diversity than the Karpuz River valley, so it should be protected first. 


\section{GÍRIŞ}

Biyoçeşitlilik yeryüzündeki tüm çeşitliliğgi kapsayan bir kavramdır. Karalar üzerinde bitki çeşitliliğinin dağılışı eşitsizdir, bitki çeşitliliği bakımından çok zengin alanlar olduğu gibi çeşitliliğin son derece az olduğu yerler de vardır (Groombridge ve Jenkins, 2002; Gaston, 2010; Mora vd. 2011). Tür çeşitlilik modelleri, biyotik ve abiyotik süreçlerin bağımsız davranışları ve mekân üzerindeki karşılıklı etkilerini ortaya koymaktadır (Fortin ve Dale, 2005; Hui, 2015). Biyoçeşitlilik birçok farklı yöntemle ölçülmektedir. İlk dönemlerdeki çalışmalarda nispeten küçük ölçekli alanlar üzerinde meydana gelen değişikliklere odaklanılırken, zaman geçtikçe bu yaklaşımın kapsamı da giderek genişlemiş̦tir (Magurran, 2005).

Biyoçeşitlilikölçüm süreci üç farklı seviyede çalışılmaktadır. Bazı çalışmalarda amaca göre seviyelerin tamamı ele alınırken bazılarında tek seviye ile de araştırma yapılmaktadır (Whittaker, 1972; Wilson ve Shmida, 1984; Legendre vd., 2005; Jost, 2007; Gülsoy ve Özkan, 2008; Özkan, 2010; Negiz, 2013; Özkan, 2016; Pinto-Ledezma vd., 2018; Avc1, 2018; Neilan vd., 2019). Bunlar; alfa çeşitlilik (alan içi çeşitliliği), beta çeşitlilik (alanlar arasındaki çeşitlilik) ve gama çeşitliliktir (alandaki toplam çeşitlilik). Alfa, beta ve gama çeşitlilik kavramı ilk olarak 1960 yılında R. J. Whittaker tarafından ortaya konulmuştur. Whittaker, batı ABD'deki Siskiyou Dağ 1 ormanlarında birçok çevresel faktöre bağlı (iklim, topografya gibi) bitki tür kompozisyonu değişimini ve türlerin alandaki kapatma oranı ile topografya ve iklim özelliklerinin değişimiyle meydana gelen tür değişimini ortaya koymuş, örnek alanlar arasındaki mesafe arttıkça kompozisyon benzerliğinin azaldığıyla ilgili çalışmalar yapmıştır (Whittaker, 1960). Konu üzerinde önemli çalışmaları olan bir diğer bilim insanı R. MacArthur, yeni bir biyoçeşitlilik ölçümü ortaya koyarak, bu indisi kuşlar üzerinde uygulamış, yöntemin farklı bir bakış açısı kazanmasını sağlamıştır (MacArthur, 1965). M. Cody de konuyla ilgili çalışmalar yapmış, alan ölçeğine bağlı farklılaşan çeşitliliğin tür sınırlılıklarını genişletmiştir (Cody, 1975). Sonraki dönemde ortaya çıkan çalışmalar çoğunlukla Whittaker ve MacArthur'un çalışmaları üzerine geliştirilmiş ancak nispeten daha az ilgi görmüştür (Tuomisto, 2010a; Tuomisto, 2010b). Biyoçeşitlilik hesaplamalarında türlerdeki farklılaşma, çeşitlilik vb. analizlere artan ilgiyle birlikte alansal, bölgesel ve küresel ölçekteki birimler sıklıkla çalışmalara konu olmaktadır (Condit vd., 2002; Buckley ve Jetz, 2007; Legendre vd., 2009; Keil vd., 2012; Wang vd., 2012; Gueze vd., 2013; Negiz, 2013; Zhang vd., 2014, Negiz ve Özkan, 2016).
Bu çalışmada Akdeniz Bölgesi’nin batısında Kargı ve Karpuz Çayı vadileri, biyoçeşitlilik durumunun ortaya konulması için örnek alan olarak seçilmiştir. Kargı Çayı vadisi, Alanya'nın 15 km batısında, büyük ölçüde kireçtaşından meydana gelen formasyonlar üzerinde açılmıştır. Florası ayrıntılı çalıșılmamasına karşılık, alanda ülke çapında nadir 26 taksonun bulunduğu bilgisi literatürde yer almaktadır. Resmi olarak koruma statüsü bulunmayan bu alan, turizm ve şehirleşme sebebiyle tehdit altındadır (Duman, 2005). Ayrıca akarsu üzerinde projesine 2014 yılında başlanan bir hidroelektrik santralinin inşaası devam etmektedir. Çevresinde Dereköy, Türktaş, Gedevet gibi yerleşim alanları bulunan akarsu, ayrıca Toros Dağları Bitkisel Çeşitlilik Merkezi (SWA No.15) olarak tanımlanan bölgede bulunur (Boulos vd, 1994). Akseki, Gündoğmuş, Manavgat gibi büyük yerleşmelerin çevrelediği Karpuz Çayı da aynı sebeplerle tehdit altındadır. Her iki alanda da beşeri faaliyetler yoğunluk kazanmaktadır. Doğal bitki örtüsünün hızla tahrip edildiği bu iki vadide, korumada öncelikli alanların tespitinde yardımcı olabilmek için alfa, beta ve gama çeșitlilik analizleri kullanılarak biyoçeşitliliğin ölçüldüğü bir çalışmanın gerçekleştirilmesi amaçlanmıştır.

\section{VERİ VE YÖNTEM}

Biyolojik çeşitliliğin ortaya konulmasında kullanılan yöntemlerden alfa ve gama çeşitlilik türdeştir. Bunların ikisinin arasındaki fark, çalışılan alanın ölçeğidir. Beta çeşitlilik ise üst topluma atfen toplumlar arası benzemezliği ifade eder (Loreau, 2000; Jost, 2007; Tuomisto, 2010a; Zhang vd., 2014; Özkan, 2016). Whittaker, beta çeşitliliği habitatlar arasındaki çeşitlilik kapsamında, örnek alanlar arasındaki tür kompozisyonu ve çeşitliliği olarak, alfa çeşitliliği tek örnek alan içindeki yerel çeşitlilik, gama çeşitliliği ise daha büyük ölçekteki çeşitliliăgi ölçmek olarak açıklamıștır (Whittaker, 1960; Whittaker, 1972). Hem alfa hem de gama çeşitlilik örnek alanlarda (kuadratlarda) ölçülür. $\mathrm{Bu}$ alanların büyüklüğü yerel çalışmalarda birkaç m2'den ülke veya kita ölçeğinde binlerce km2'ye kadar değişebilir (Veech ve Crist, 2007).

Alfa çeşitlilik farklı yollarla hesaplanmaktadır. En basiti örnek alandaki türlerin bireylerini saymaktır. Whittaker'ın ardından ekoloji literatüründe alfa çeşitliliği ölçmek için birçok indis oluşturulmuştur. Örnek alanda türleri saymak dışında alfa çeşitlilik ölçümü iki farklı grupta ele alınan yöntemlerle yapılabilir. Bunlar tür zenginlik tahminleri ve çeşitlilik indisleridir. Tür zenginlik tahmini bir birlikte veya örnek alanda var olan türlerin yaklaşık oranıdır. Çeşitlilik indisleri ise heterojenik indislerdir ve eşitliğin tek değeri içinde hem tür 
zenginliğini hem de yoğunluğu ile ifade edilir. Bir türün baskın olduğu birlikler zayıf eşitlik değeri verirken türlerdeki yoğunluğun eşit olduğu birlikler yüksek eşitlik değeri verir (Volkov vd., 2003; Cayuela vd., 2006).

Kavramsal olarak beta çeşitlilik iki önemli bileşenin veya seviyenin yani alfa veya gama çeşitliliğinin birleşimidir. Alfa çeşitlilik yerel çeşitliliği veya tek bir yer içindeki çeşitliliği, gama ise alansal çeşitliliği veya birden fazla birlik alanının toplam çeşitliliğini ifade eder (Jurasinski vd., 2009). Çevresel süreçler, özellikle lokal ölçekte (alfa) veya alansal ölçekte (gama) tür çeşitlilik kompozisyonunun güncel durumu hakkında bilgi verir. Kısacası beta çeşitlilik alanlar arasındaki tür kompozisyonu değişimidir; bir alandaki tür kompozisyonunu ifade eden envanter unsurlarını karşılaştırarak çeşitliliğin farklılaşma bileşenlerini ortaya koyar (Whittaker 1960; Whittaker 1972; Harrison vd., 1992; Özkan, 2016).

Beta çeşitlilik, çeşitlilik kaybının mekansal ölçeklenmesini ortaya koyduğu gibi, bölgesel çeşitlilik koruma mekanizmalarını aydınlatır. Beşeri faaliyetler beta çeşitliliğinin artmasına, azalmasına veya değişmeden kalmasına neden olabilir. Beta çeşitliliğin korunmasının önemi, yerel çeşitlilik dinamiklerine bağlı olarak değişir (Socolar vd, 2016).

Toplam çeşitlilik veya gama çeşitliliği $(\gamma)$ ise bir alandaki türlerin tamamının çeşitlilik değerini ifade eder. Alfa ve beta çeşitlilik bileşenleri ile hesaplanan gama çeşitlilik (Tuomisto, 2010a) Whittaker tarafından alfa ve beta çeşitliliğinden etkilenen tarihsel ve evrimsel süreçlere bağlı bir değer olarak açılanmıştır (Whittaker, 1972). Kısaca gama çeşitlilik bir alandaki topluluk için kaydedilen toplam tür sayısı olarak özetlenebilir ve bu indis birden fazla alanın tür çeşitlilik karşılaştırmasında kullanılan yöntemlerden biridir. Gama çeşitliliğin doğru sonuç verebilmesi için örnek alan sayısının fazla olması önemlidir. Diğer bir deyişle, gama çeşitlliliğin uygulandığı alan büyüdükçe veya örnek alan sayısı arttıkça indis daha güvenilir sonuç vermektedir.

Tür çeşitliliği genellikle sadece var, var-yok veya kantitatif tür-yoğunluk verileri ile belirlenir. Sadece var verisi türlerin bilinen alanlarının listesini içerir, ancak var-yok verisi tür bireylerinin bilinen varlıklarından yola çıkarak bulunuşlarını ifade eder ve genellikle tür dağılış poligonlarıla temsil edilir. Var-yok verisi tür bireylerinin dağılışına bağlıdır. Tür yoğunluk verisi ise kantitatiftir ve örnek alandaki türlerin birey sayısına dayanır (Tuomisto, 2010b; Özkan, 2016). Alanın genişliği ve uygulama maliyeti gibi sınırlılıklar çerçevesinde tüm biyoçeşitliliği ortaya koymaya çalışan beta çeşitlilik, koruma planlaması için çok önemli veri sağlar. Toplam tür sayısı, endemik türler veya tehdit altındaki türler sahanın göreceli önemine katkı sağlarken, koruma alanlarının mekânsal dağılışını belirleyen asıl unsurları da ortaya koyar. Beta çeşitlilikte var-yok verisi ile tür yoğunluğunun birlikte kullanımı bu yöntemi diğerlerinden ayırmaktadır. Yöntem seçimi topluluk yapısındaki mekânsal değişimin yorumlamasını dahi değiştirebileceğinden oldukça önemlidir (Pimm ve Gittleman, 1992; Nekola ve White, 1999; Anderson vd., 2011).

Biyoçeşitlilik hesaplamalarının temelini oluşturan envanter hazırlama süreci öncesinde çalışma alanının sınırlandırılması, örnek alanların seçimi, çeşitliliğe dahil edilecek bitki katlarının belirlenmesi gibi birçok özellik göz önünde bulundurularak bir ön hazırlık gerçekleştirilir. Bu aşamadan sonra arazide titizlikle yürütülen çalışmalar envanterin doğru hazırlanmasını sağlayacaktır. Bu iki büyük akarsu vadilerinde yukarı, orta ve aşağ vadilerin hem kendi içinde hem de birbirine göre hangisinin korumada öncelik olacağ 1 ortaya konulmaya çalışılmıştır. Çalışmamızda var-yok verisi kullanılmış, örnek alanlarda görülen bitki taksonları alandaki yoğunluk yüzdelerine göre ele alınmıştır.

$\mathrm{Bu}$ çalışmada tüm bitki katları incelenerek örnek alanlarda her bitki topluluğu için kaplama alanı değerleri ve yetişme ortamı özellikleri kaydedilmiştir. Örnek alan sayısı kadar alfa çeşitlilik değişkeni mevcuttur. Örnek alanlarda her bir kat ve ayrıca örnek alanın tümü için alfa çeşitlilikler tespit edilmiş ve tür adları kodlanmıştır. Beta çeşitlilik her örnek saha için örnek alanlar arası farklılığ 1 ifade eden tek değerdir. Her bir bitki katının ve genelinin örnek saha bazında örnek alanlar arası beta çeşitliliği tespit edilmiş ve kodlanmışı̂r (Şekil 1). Çeşitlilik indislerinin hesaplanmasında; alfa tür çeşitliliği için ShannonWiener indisi $(\boldsymbol{\alpha} \boldsymbol{H})$, beta çeşitlilik için, Whittaker'ın beta çeşitlilik $(\boldsymbol{\beta} \boldsymbol{w})$ indisi kullanılmıştır. İki vadinin bitki çeşitliliği karşılaşmasında ise Whittaker'ın gama çeşitlilik $(\gamma)$ indisi kullanılmıștır.

Kargı Çayı, Alanya'nın 15 km batısında olup yatağı büyük ölçüde kireçtaşları üzerindedir. Akarsu vadisinin aşağı ve yukarı çığırında üst yamaçlar yoğun kızılçam ormanlarıyla kaplıdır. $\mathrm{Bu}$ ormanlara yer yer saçlı meşe (Quercus cerris), gürgen yapraklı (Ostrya carpinifolia) kayacık bireyleri karışmaktadır. Akarsuyun denize ulaştığı kesiminde ve orta çı̆̆ırda güney bakıdaki kızılçamlar, üst çığıra kadar doğu-batı doğrultusunda olan akarsuyun buradan itibaren kuzey-güney doğrultusunu kazanması nedeniyle doğu ve batı yamaçlarda yayılış göstermeye 
Şekil 1: Çalışmanın akış diyagramı.

Figure 1: Research flow diagram.

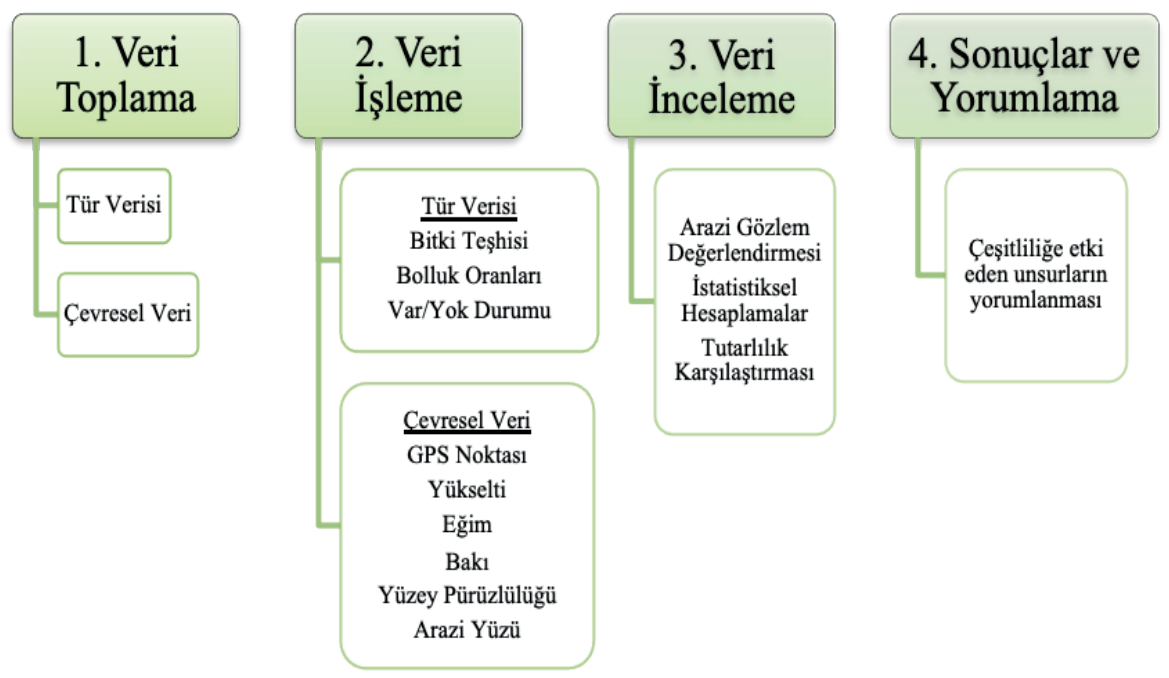

başlar. Yükseltinin 1500 metrelere ulaştığı akarsuyun kaynak kısımlarına gidildikçe göknar ve sedir toplulukları ortaya çıkar. Vadi güneyde kahverengi orman toprakları, kaynak civarında ise kireçsiz kahverengi orman toprakları ile çevrilidir.

Karpuz Çayı vadisi karasal kırıntılılar ve kireçtaşları üzerinde açılmıştır. Karpuz Çayı'nın orta çığırında yoğunlaşan kızılçam toplulukları üst çığıra yakın doğu-batı doğrultulu Gülen Dağ’ın güney yamaçlarında yükseltinin artmasına bağlı olarak kesintiye uğrasa da kuzey-güney yönlü vadi çevresinde tekrar yoğunluğunu artırır. Karpuz Çayı vadisi alçak kesimlerde kahverengi orman toprakları, üst havzasında ise kırmızı Akdeniz toprakları yayılış gösterir.

Karpuz Çayı ve Kargı Çayı'nda yıllık ortalama sıcaklık $16^{\circ} \mathrm{C}-20^{\circ} \mathrm{C}$ arasında değişir. Ocak ayı ortalama sıcaklıklar $8-12^{\circ} \mathrm{C}$; Temmuz ayı ortalama sicakliklar ise $24-28^{\circ} \mathrm{C}$ arasında seyreder. Her iki vadide de vejetasyon devresi süresi 271 ila 365 gün arasındadır. Akarsuların denize ulaştıkları aşağı kesimlerine yakın bölgelerde yetişme devresi yıl boyunca devam ederken bu süre iç kesimlere doğru yükselti arttıkça azalır. Yıllık ortalama yağış miktarı her iki vadide de 1000 -1500 mm arasında değişir. Yağışın aylara dağılışına bakıldığında belirgin bir yaz kuraklığı görülmektedir. Toplam yağışın yarısından fazlası kış aylarında düşmektedir. Bu iki akarsu vadisi De Martonne kuraklık indisine göre yarıkurak-nemli, Erinç yağış etkinlik indisi formülüne göre ise nemli koşullara sahip alanlardır.

Alfa, beta ve gama analiz sonuçlarının güvenilir ve anlamlı sonuçlar vermesi için örnek alan lokasyonlarının seçimi, miktarı,

bitki örnek sayısı ve bolluk yüzdelerinin doğru belirlenmesi önem taşır. Arazi çalışması öncesinde çalışma alanı olarak seçilen Kargı ve Karpuz Çayı vadileri 10×10 metre genişliğinde eşit karelere bölünmüştür. CBS ortamında Fishnet aracılığıyla belirlenen bu örnek alanlar yalnızca referans olarak kullanılmış, esas örneklem sahaları arazi çalışmalarındaki gözlemlerle bitki çeşitliliğinin ve bolluğun fazla olduğu alanlardan seçilmiştir. Ayrıca örnek alanların beşeri faaliyetlerin etkili olduğu yerleşim yerleri ve çevreleri ile tahrip alanlarının uzağında olmasına dikkat edilmiştir (Harita 1, Harita 2 ve Harita 3 ).

Her bir akarsu vadisi için 80, toplamda 160 örnek alandan (Harita 3), 175 farklı bitki örneği toplanmıştır. Seçilen örnek alanlar GPS ile işaretlenip, şerit metre yardımıyla çevrilerek örnek alanlar (kuadratlar) oluşturulmuştur. Bu karelerin içinde bulunan tüm ot, çalı ve ağaçlardan örnek toplanmış, bitkilerin bolluk durumu Braun Blanquet yöntemine göre saptanmıştır. Bitkilerin listesi ve bolluk yüzdeleri hemen o sırada her bir örnek alan için hazırlanan envanter kayıt raporlarına işlenmiştir.

Örnek alanlardaki bitkiler tanımlanarak (Davis, 1965-1985; Davis vd, 1998; Güner vd, 2000), tüm bitki adları ve bolluk oranlar1 Microsoft Excel ortaminda veri matrisine dönüştürülmüştür. $\mathrm{Bu}$ işlem yapılırken bitkilere kod adları verilmiş, tüm örnek alanlar bir çalışma sayfasında toplanarak analizlerin altlık verisi tamamlanmıştır (Tablo 1).

$\mathrm{Bu}$ adımdan sonra elde edilen verilerin tamamı bir dizi matematiksel hesap ve program dönüştürücüsüne tabi tutulmuştur. 


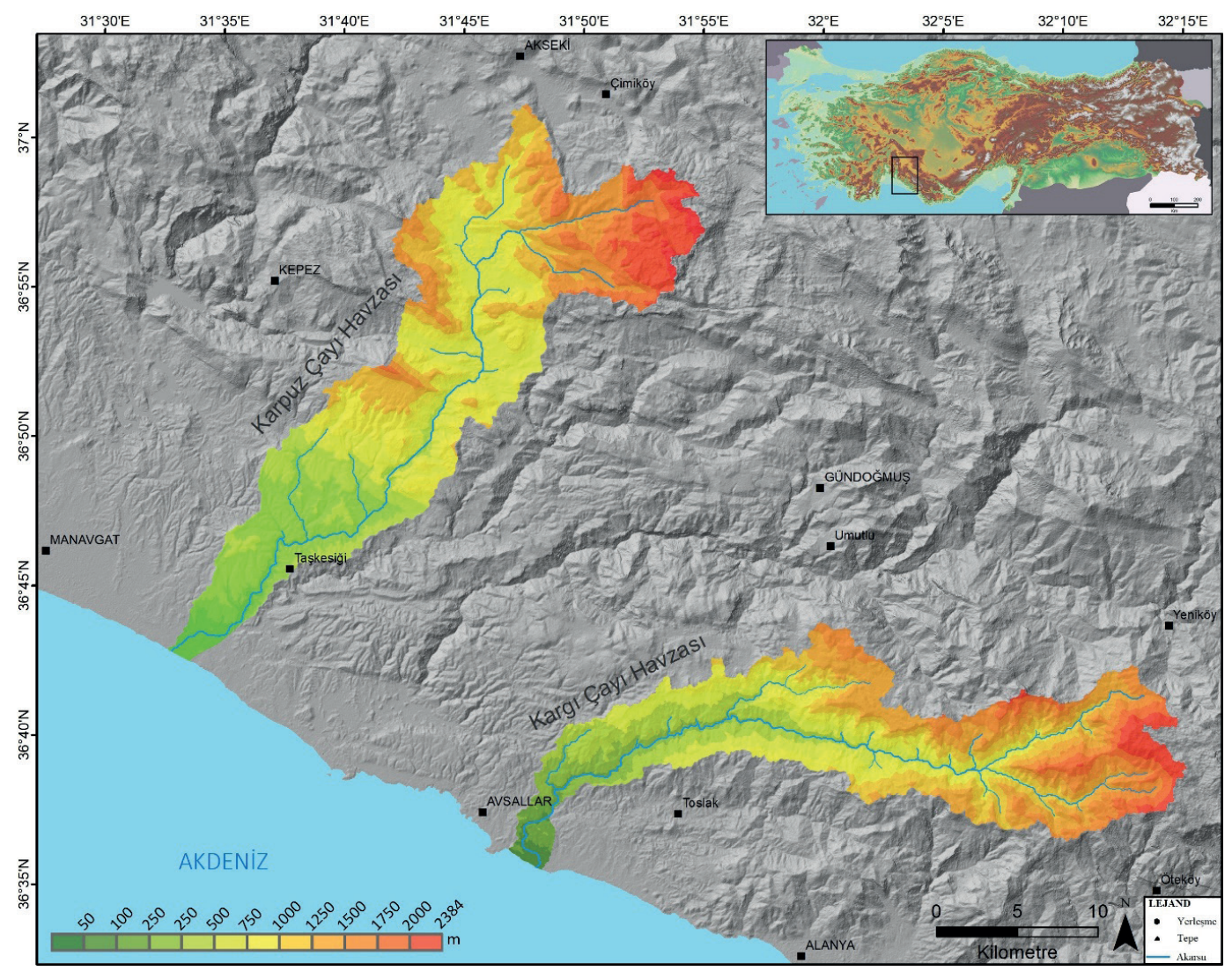

Harita 1: Çalışma sahasının yeri.

Map 1: Locations of river valleys.

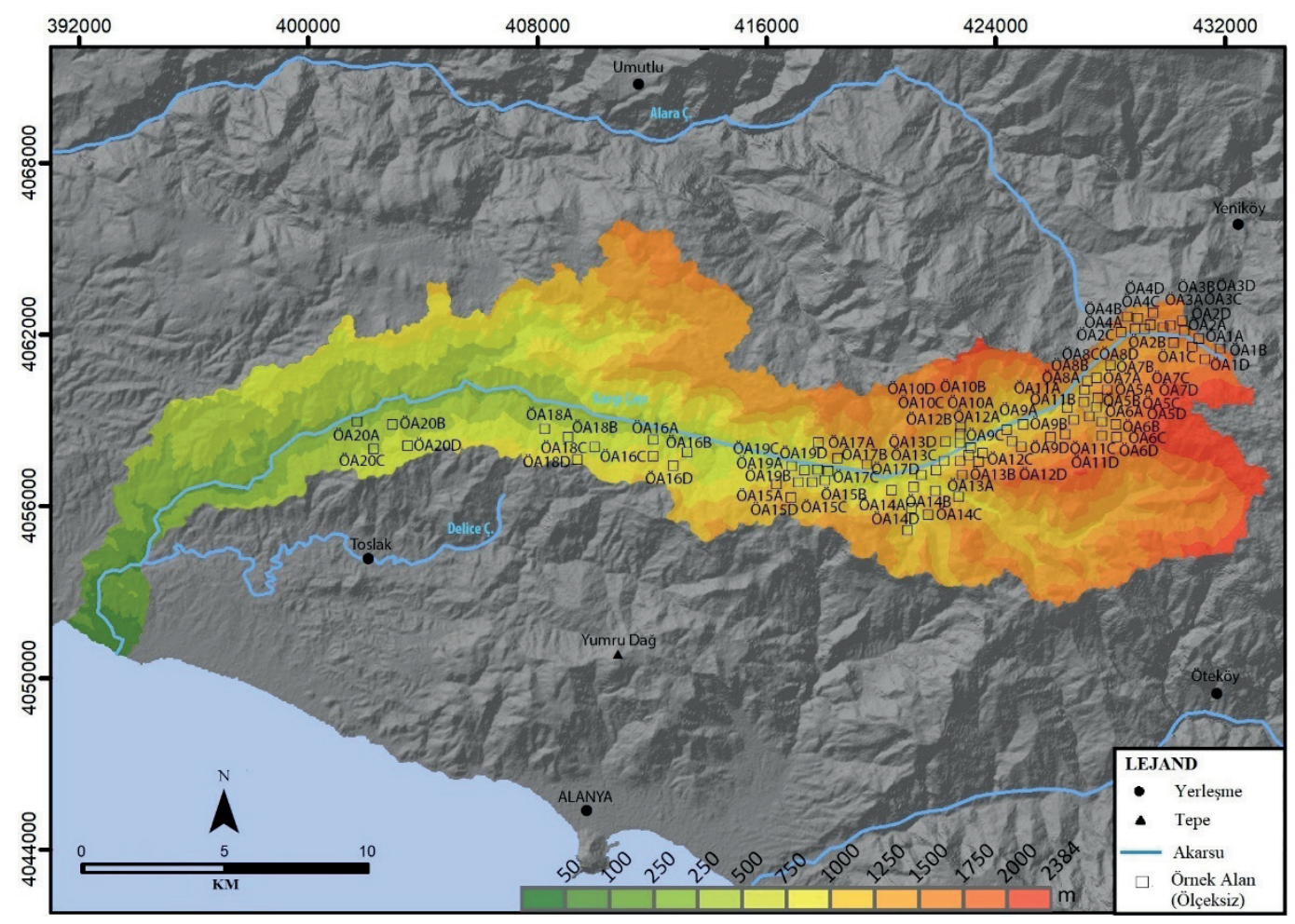

Harita 2: Kargı Çayı vadisinde oluşturulan örnek alanların lokasyonları. Map 2: Locations of the sample areas in Kargı River valley. 


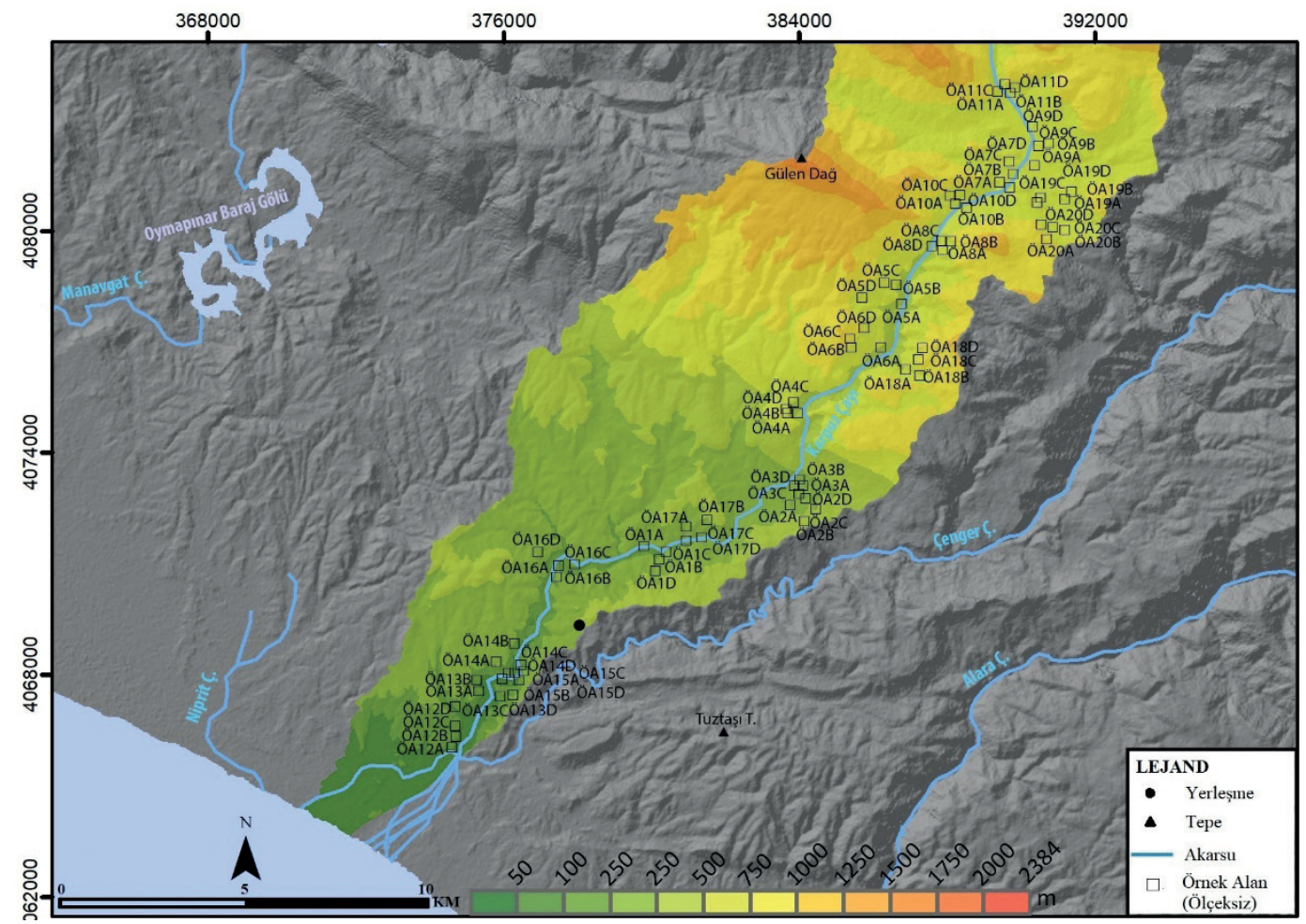

Harita 3: Karpuz Çayı vadisinde örnek alanların lokasyonları.

Map 3: Locations of the sample areas in Karpuz River valley.

$\mathrm{Bu}$ amaçla Karpuz Çayı $(35 \mathrm{~km})$ ve Kargı Çayı $(43 \mathrm{~km})$ vadilerinde toplanan bitki taksonlarını gösterir matris oluşturulmuş ve her bir taksonun örnek alanlardaki bolluk

Tablo 1: Bitkilerin bilimsel adları ve bolluk verilerinden oluşturulan altlık verisine bir örnek.

Table 1: An example of base data created from species names and abundance rate of plants.

\begin{tabular}{lc}
\hline TÜR & BOLLUK (\%) \\
\hline Asparagus acutifolius & + \\
Capparis zoharyi & 1 \\
Cercis siliquastrum & 0,5 \\
Cupressus sempervirens var. horizantalis & 3 \\
Daphne gnidioides & 0,1 \\
Dittrichia viscosa & 0,5 \\
Heliotropium hirsutissimum & r(rare=nadir) \\
\hline
\end{tabular}

dereceleri işaretlenmiştir. Örnek alanlardaki tüm taksonların bolluk derecesi Braun-Blanquet skalasından Westhoff ve Maarel kaplama alanına dönüştürülerek altlık oluşturulmuştur (Tablo 2 ve Tablo 3). Son olarak alfa indisi, var-yok veri matrisine dönüştürülerek yeni matris oluşturulmuştur. Var-yok verisi her bir örnek alanda bitki taksonlarının var olup olmadığını gösteren matristir.

Var-yok verileri ile alfa çeşitlilik grafiği oluşturulduktan sonra evrensel beta değerleri hesaplanmıştır. Dört alt örnek alanın bir evrensel beta alanı oluşturduğu bu indisin sonucunda her bir akarsu vadisi için 20'şer, toplamda 40 örnek alan değeri ortaya çıkmıştır. Örnek alanların kendi içerisinde oransal açıdan bitki çeşitliliğinin elde edildiği evrensel beta çeşitlilikte 8 ayrı

Tablo 2: Kaplama alanı yüzdelerinin Braun-Blanquet skalasının Westhoff ve Maarel skalası karşılığı (Westhoff ve Maarel, 1980). Table 2: Equivalent of coverage area percentages between Braun-Blanquet scale and Westhoff and Maarel (Westhoff and Maarel, 1980).

\begin{tabular}{|c|c|c|c|c|}
\hline & \multicolumn{2}{|c|}{ Braun-Blanquet Skalası } & \multicolumn{2}{|c|}{ Westhoff ve Maarel (1980) } \\
\hline & Sinıf & Kapatma Oranı & Sinif & Kapatma Oranı \\
\hline $\mathrm{a}$ & $r$ & Bir veya birkaç birey & 1 & Nadir \\
\hline $\mathrm{b}$ & + & $<\% 1$ & 2 & Seyrek \\
\hline C & 1 & $\%<5$ & 3 & $\%<5$ \\
\hline def & 2 & $\% 5-25$ & $4,5,6$ & $\% 5-25$ \\
\hline$g$ & 3 & $\% 25-50$ & 7 & $\% 26-50$ \\
\hline $\mathrm{h}$ & 4 & $\% 50-75$ & 8 & $\% 51-75$ \\
\hline $\mathrm{k}$ & 5 & $\% 75-100$ & 9 & $\% 76-100$ \\
\hline
\end{tabular}


Tablo 3: Örnek alanlarda Westhoff ve Maarel (1980)'e göre hazırlanan var yok veri örneği.

Table 3: An example of a presence-absence data base of sampling areas prepared according to Westhoff and Maarel (1980).

\begin{tabular}{|c|c|c|c|c|c|c|c|c|c|c|c|c|c|c|c|c|c|c|c|c|}
\hline & $\frac{\stackrel{0}{\frac{0}{0}}}{\frac{\mathrm{U}}{0}}$ & ํㅡㄹ & 동 & 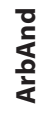 & $\frac{\text { ż }}{\frac{0}{4}}$ & $\frac{\dot{0}}{\text { ñ }}$ & 玄 & $\begin{array}{l}\text { 응 } \\
\text { 응 }\end{array}$ & ํํㄴ & $\frac{n}{\frac{n}{d}}$ & 玄 & ํㅡㄴ & 衣 & $\frac{\underline{E}}{\mathfrak{U}}$ & $\underset{\cup}{U}$ & $\frac{0}{n}$ & $\underset{3}{\overline{3}}$ & $\frac{\bar{n}}{\bar{v}}$ & త్ & ঠூ \\
\hline 01A & $x$ & $r$ & $x$ & 23 & + & $x$ & $x$ & $x$ & $x$ & $x$ & 30 & + & $x$ & $x$ & + & $x$ & $x$ & + & $x$ & $x$ \\
\hline O1B & $x$ & $x$ & $x$ & 15 & + & $x$ & $x$ & $x$ & $x$ & $x$ & 25 & 1 & $x$ & $x$ & $x$ & $x$ & $x$ & $x$ & $x$ & $x$ \\
\hline $01 C$ & $x$ & $x$ & $x$ & 15 & + & $x$ & $x$ & $x$ & $x$ & $x$ & $x$ & $x$ & $x$ & $x$ & $x$ & $x$ & $x$ & $x$ & $x$ & $x$ \\
\hline O1D & $x$ & $x$ & $x$ & 20 & + & $\mathrm{x}$ & $x$ & $x$ & $x$ & $x$ & 30 & $\mathrm{x}$ & $\mathrm{X}$ & $x$ & $x$ & $\mathrm{x}$ & $x$ & $x$ & $x$ & $x$ \\
\hline
\end{tabular}

indis değeri hesaplanmış ancak en fazla kullanılan Whittaker'ın beta çeşitlilik $(\boldsymbol{\beta} \boldsymbol{w})$ indisine göre yorumlanmıştır. Son olarak da Whittaker'ın gama çeşitlilik $(\gamma)$ indisi ile iki vadinin bitki çeşitliliği karşılaş̧ırılmıştır.

\section{BULGULAR}

Karpuz Çayı'nda en yüksek alfa bitki çeşitliliği ÖA3A, ÖA5B, ÖA14A, ÖA1A ve ÖA8A; en az alfa bitki çeşitliliği ise ÖA7B, ÖA11D, ÖA10D, ÖA19D ve ÖA20C örnek alanlarında tespit edilmiştir. Çeşitliliğin yüksek olduğu örnek alanların tamamı terra rossalar üzerindedir. ÖA3A, $100 \mathrm{~m}$ yükseltide çayın orta çığırında yer alır. 33 bitki taksonu kaydedilmiş olup, Cupressus sempervirens var. horizontalis, Vitex agnus-castus, Pistacia terebinthus subsp. palaestina, Pistacia terebinthus subsp. terebinthus, Teucrium polium, Vitis vinifera dikkat çeken bitkilerdendir. ÖA5B ise 680 metre yükseltide, yukarı çığırdadır ve buradan 26 bitki taksonu toplanmıştır. Karpuz çayının mevsimlik akışa geçen bir kolunun yer aldığı bir vadi üzerindedir. Suyun dönemsel varlığı akarsu yatağındaki bitkilerden de kolayca fark edilmektedir. Yatak içerisinde Alnus orientalis var. pubescens, Platanus orientalis, Ostrya carpinifolia, Nerium oleander yayılış gösteren bitkilerden bazılarıdır. Ağaçların kapatma oranı oldukça yüksektir ve çevre çoğunlukla kızılçam ormanlarıyla örtülüdür.

ÖA14A, akarsuyun ağız kısmına çok daha yakın aşağı çığır kesiminde, $50 \mathrm{~m}$ yükseltidedir. Çayın hemen yanındaki yamaç üzerinde oluşturulan bu örnek alanda toplam 24 bitki taksonu kaydedilmiştir. Tamarix sp., Cotinus coggygria, Xanthium strumarium subsp. cavanillesii, Phragmites australis, Heliotropium hirsutissimum alandaki ekolojik ortamın göstergesi olan bitkilerden bazılarıdır. ÖA1A, 300 metre civarında, akarsuyun orta çı̆̆ırındadır. Yoğun bir kızılçam popülasyonuna sahip olan örnek alanda Quercus cerris, Quercus trojana ve Quercus coccifera gibi meșe türleri de yayılış gösterir. Bunların yanı sira Cupressus sempervirens var. horizontalis, Ceratonia siliqua ile ağaçların neredeyse tamamına sarılmış Smilax aspera ve Smilax excelsa bulunmaktadır. Nispeten açık alanlarda ise tipik maki formasyonu elemanları görülmektedir. ÖA8A, 450 m'de örtü derecesinin az olduğu, çoğunlukla toprağın süpürülüp kireçtaşı anakayanın yüzeylendiği ve eğim derecesi fazla olan bir alandır. Bazı yerlerde maki formasyonu da tahrip edilmiştir. $\mathrm{Bu}$ örnek alanda 19 takson tespit edilmiştir. Pinus brutia, Juniperus excelsa, Olea europea var. europea, Myrtus communis, Trifolium angustifolium var. angustifolium, Echinops sp. bunlardan bazılarıdır.

Alfa bitki çeşitliliğinin en az olduğu ÖA7B, ÖA11D, ÖA19D ve ÖA20C de terra rossalar üzerindedir. ÖA10D ise kahverengi orman toprakları yayılış alanındadır. Bu örnek alanların benzerliği birbirlerinden uzak ve farklı yükselti, eğim ve bakılarda olsalar dahi akarsu çevresindeki yerleşim yerleri yakınlarında bulunmalarıdır. Her bir örnek alanda en fazla 10 en az 7 farklı bitki taksonu kaydedilmiştir (Şekil 2, Harita 4).

Karpuz Çayı vadisinde en yüksek evrensel beta çeşitlilik ÖA14 ile ÖA3, ÖA6, ÖA18 ve ÖA11'de; en düşük çeşitlilik ise ÖA2 ile ÖA9, ÖA13, ÖA10 ve ÖA12'de görülmektedir. Aynı vadi içerisinde kayda değer oranda farklılık gösteren bu alanlar konum ve ekolojik özelliklerine göre sınıflandırılmıştır. ÖA14, yükseltisi $50 \mathrm{~m}$ olan, eğimin $15-25^{\circ}$ aralığında değiştiği, kahverengi orman toprağı üzerinde düze yakın bir alandır. Akarsuyun menderesler çizdiği aşağı çığıra denk gelen bu saha, vadisinin tamamında çeşitliliğin en fazla görülüğü yerlerden biridir. Bir diğer yüksek çeşitlilik değeri veren ÖA3, $100 \mathrm{~m}$ yükseltide, $0-15^{\circ}$ eğim aralığında, terra rossanın görüldüğü bir sahadır. Akarsu vadisi içinde ve yamacın alt kısmında bulunan bu örnek alan Gençler mevki yakınlarında olup denizden uzaklığı yaklaşık 16 km'dir. ÖA6, 370 m yükseltide, $25-35^{\circ}$ eğimli, batıya dönük, terra rossanın görüldüğü diğer bir yükssek çeşitlilik alanıdır. Akarsu vadisinde su bölümü hattına yakın olan ÖA6'da çoğunlukla yüzeylenen kireçtaşı formasyonlar, çeşitli maki türleriyle kaplıdır. ÖA18 ise, $700 \mathrm{~m}$ yükseltide bulunmaktadır. Eğim $25-35^{\circ}$ arasında, güneydoğu bakılıdır. Terra rossanın görüldüğü alan Akseki-İbradı arasındaki Toros Yolu üzerindedir ve makilere karışık birçok otsu 


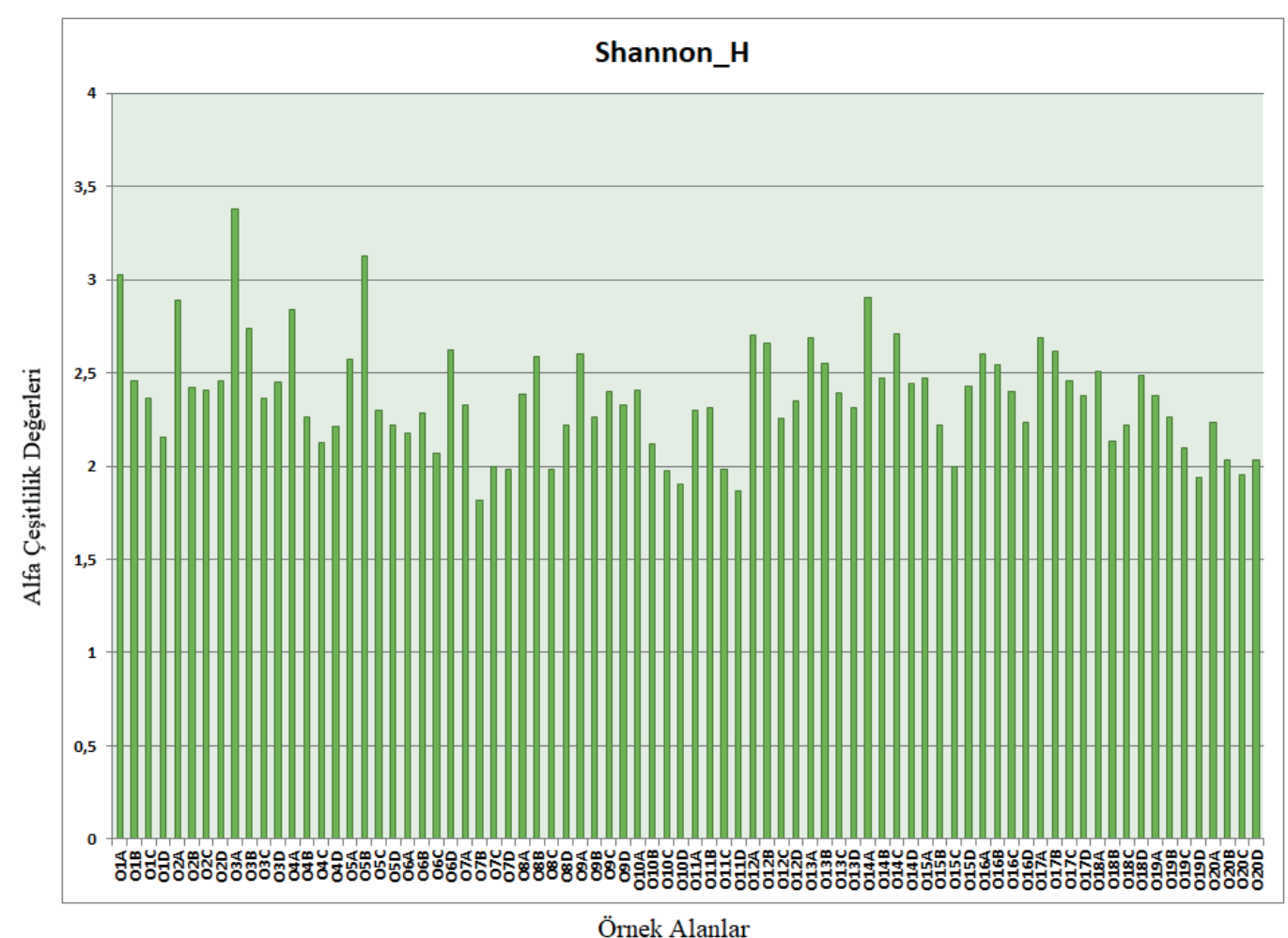

Şekil 2: Karpuz Çayı vadisindeki örnek alanlarda alfa çeşitlilik oranları (örnek alan sıralamasına göre verilmiştir).

Figure 2: Alpha diversity rates in the sample areas in the Karpuz River valley (given in order of sample area).

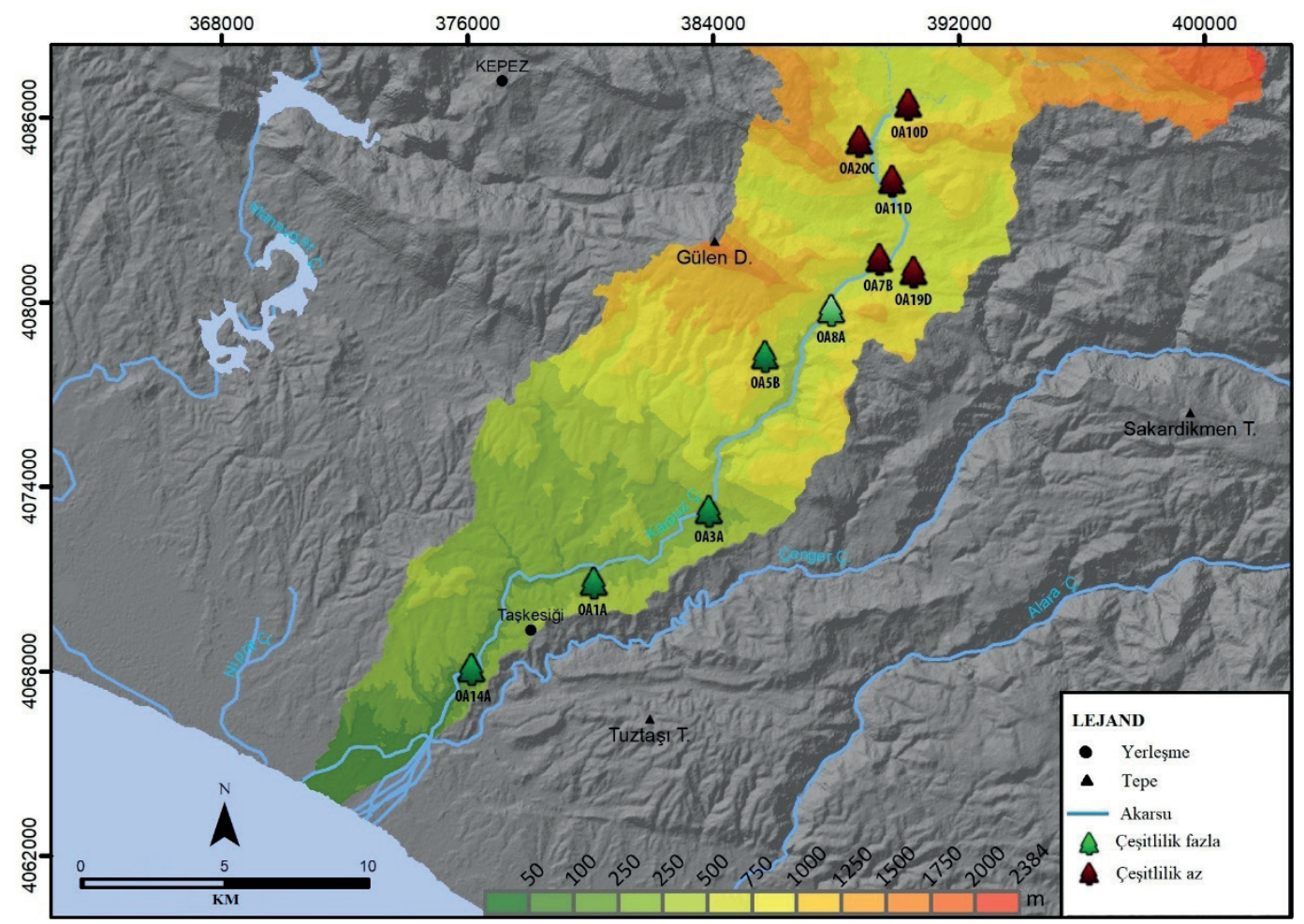

Harita 4: Karpuz Çayı vadisinde alfa çeşitliliğin en yüksek ve en az olduğu örnek alanlar. Map 4: Sample areas where the alpha diversity is highest and lowest in the Karpuz River valley. 
taksonu barındırmaktadır. Son olarak ÖA11 de, 600 m'de, eğimi $0-15^{\circ}$ aralığında değişen, doğu bakıya sahip, terra rossa ile kaplı bir alandır. Bu kesimde daha çok çalı ve odunsu bitki çeşitliliği bulunmaktadır.

Evrensel beta çeşitliliğinin düşük olduğu örnek alanların başında ÖA2 gelmektedir. Burası $200 \mathrm{~m}$ yükseltide, 15-25 eğim aralığındadır ve toprak tipi terra rossadır. Akarsuyun yukarı çı̆̆ırında kapalılığı az orman sahasında bulunur. ÖA9, $450 \mathrm{~m}$ yükseltiye, 0-15 eğime sahip terra rossanın üzerinde kuzeybatı bakılı düşük çeşitliliğe sahip bir diğer alan olarak tanımlanmıştır. Saf bir kızılçam ormanıyla kaplı bu bölgede orman altı örtüsü oldukça zayıftır. ÖA13 ise, 50 m yükseltide bir menderes büklümünün içinde, eğimi $15-25^{\circ}$ arasında değişen bu lokalitenin toprakları, alüvyal topraktır. Debinin arttığı ilkbahar mevsiminde bitkilerin bu adacıkta tutunması güçtür. Ancak özellikle kıyı bitkileri bu kesimde oldukça geniş bir yer kaplamaktadır. ÖA10 örnek alanı $650 \mathrm{~m}$ yükseltide $0-15^{\circ}$ eğime sahiptir. Doğu bakılı bu sahadaki toprak tipi, terra rossadır. Orman tahrip edilmiştir ve garig formasyonu baskındır. Son olarak ÖA12, $50 \mathrm{~m}$ yükseltide $0-15^{\circ}$ eğimli, kahverengi orman toprakları üzerindedir. Aşağı çığır civarındaki bu alan, kızılçam ve maki formasyonunu birlikte barındırır ve vadideki büyük yerleşim alanlarına yakındır.

Karpuz Çayı'nda beta çeşitliliğin artı̧̧ ve azalış sebepleri ekolojik koşullardan ziyade beşeri faaliyetlere uzaklık ve yakınlık ile farklılık göstermektedir (Şekil 3, Harita 5). Evrensel beta çeşitlilik haritasından da görüleceği üzere Karpuz Çayı vadisinin aşağı ve yukarı çığırlarına denk gelen kesimlerdeki yerleşim (Hacıobası, Uzunlar, Gençler gibi) ve tahrip alanlarına yakın mevkilerdeki örnek alanlar genelde düşük çeşitliliğe sahiptir. Akarsu vadisinin orta kesimine denk gelen ve kesintisiz kızılçam topluluklarıyla kaplı Taşkesiği mevkinin kuzeybatısındaki örnek alanlar ile akarsuyun doğduğu, beşeri faaliyetlerden uzak Ahmetler, Güçlüköy kuzeyindeki örnek alanlar yüksek beta çeşitliliğe sahiptir. Karpuz Çayı vadisinin doğal bitki çeşitliliğii, yerleşme, tarım, turizm faaliyetlerinin yarattığı baskı nedeniyle tehlike altındadır.

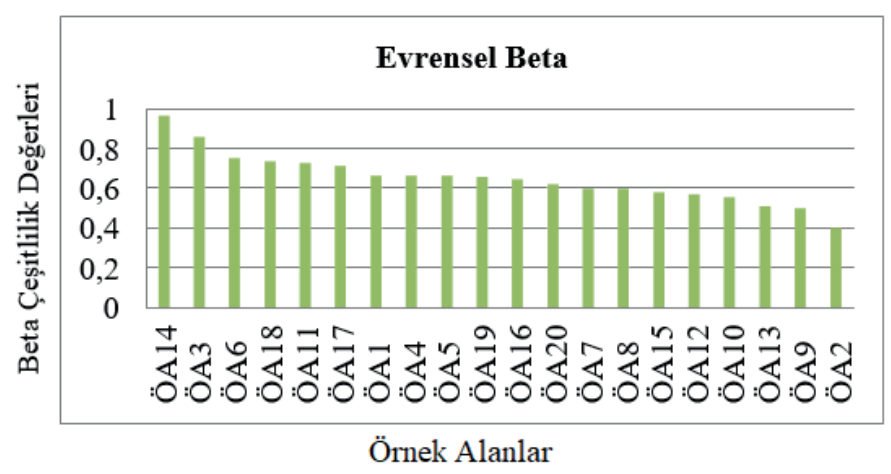

Şekil 3: Karpuz Çayı vadisindeki örnek alanlarda beta çeşitlilik oranları (en yüksek değeri içeren alandan en düşük değere doğru sıralanmıştır).

Figure 3: Beta diversity rates in the sample areas in the Karpuz River valley (ranked from the highest value to the lowest value).

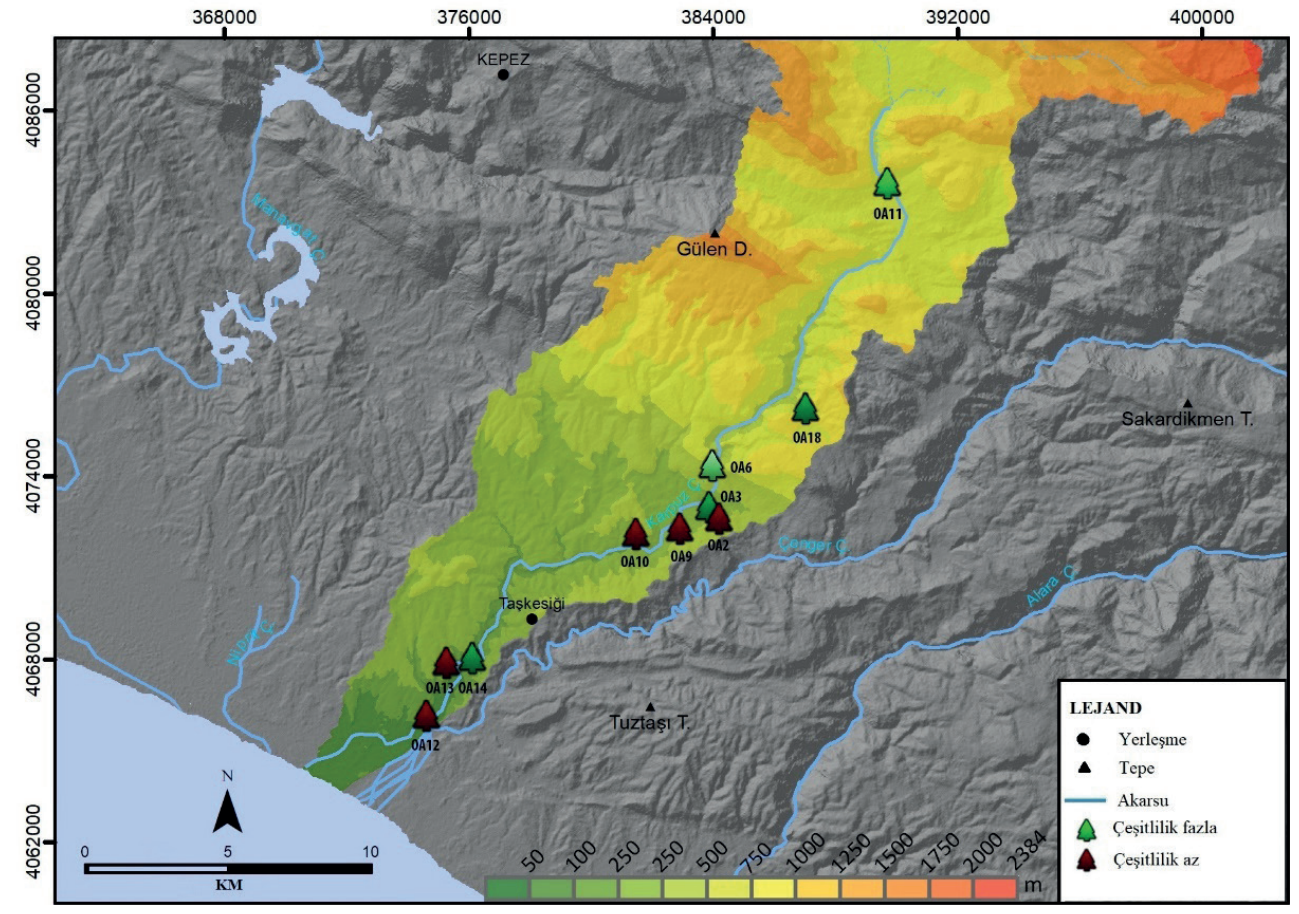

Harita 5: Karpuz Çayı vadisinde beta çeşitliliğin en yüksek ve en az görüldüğü örnek alanlar. Map 5: Sample areas where beta diversity is the highest and lowest in Karpuz River valley. 
Alfa ve beta çeşitlilik analizleri Kargı Çayı vadisi için de yapılmıştır. Bunun için vadide belirlenen 80 örnek alanda toplam 147 farklı bitki taksonu toplanmıştır. Kargı çayında en yüksek alfa biyoçeşitliliğge sahip örnek alanlar; ÖA18 ile ÖA20A, ÖA8A, ÖA9A, ÖA11A, en az bitki çeşitliliğgine sahip örnek alanlar ise ÖA17C, ÖA15C, ÖA1D, Ö17B ve ÖA17D olarak belirlenmiş̧ir (Şekil 4, Harita 6). ÖA18A, akarsuyun orta çığırında oldukça dar ve derin bir vadinin aşağı yamacındadır. Bitki çeşitliliğinin çok ve yoğun olduğu bu kesimde talveg yaklaşık 700 m'de, vadi derinliği ise 83 m'dir. Söz konusu örnek

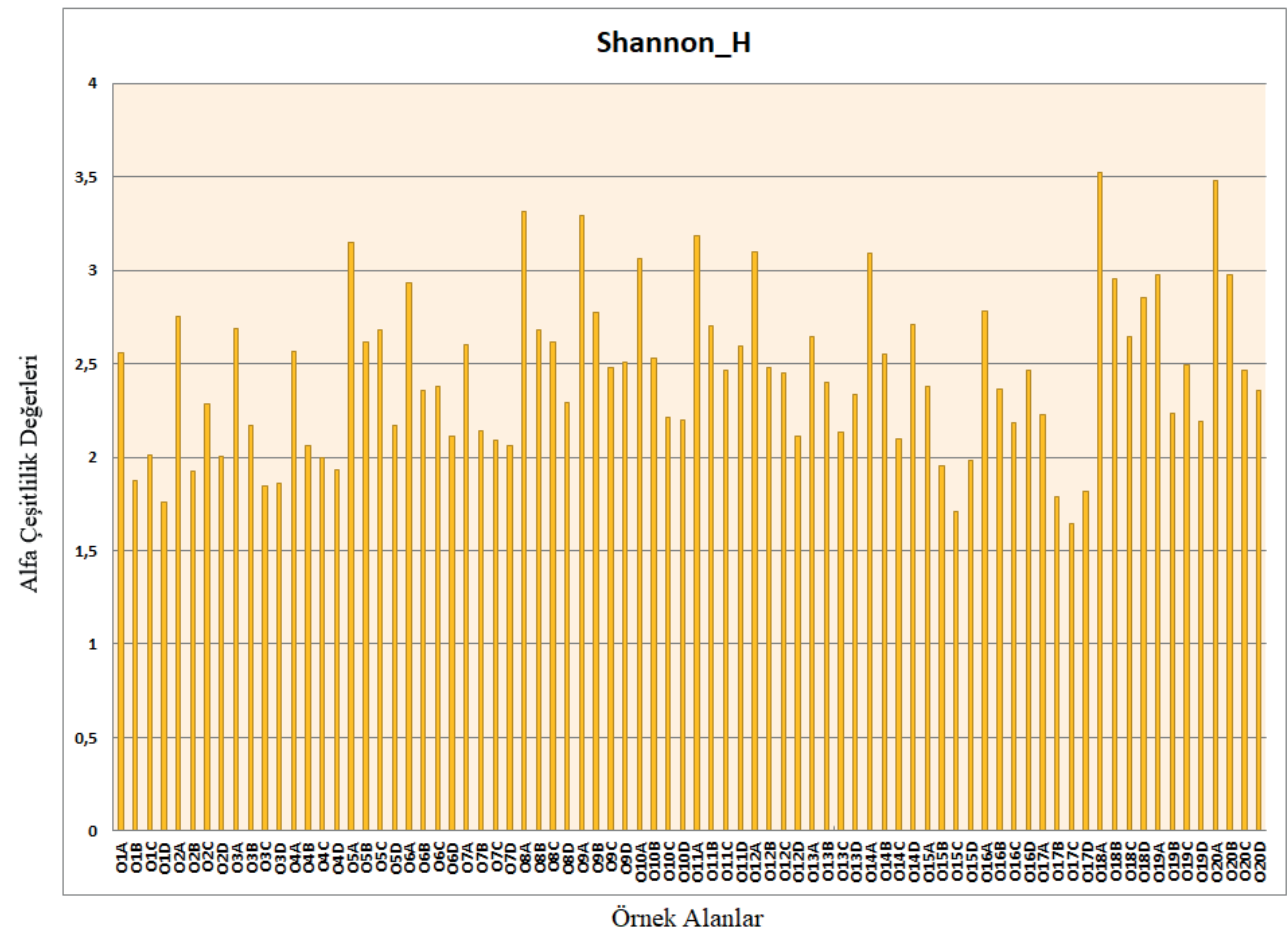

Şekil 4: Kargı Çayı vadisindeki örnek alanlarda alfa çeşitlilik oranları (örnek alan sıralamasına göre verilmiştir).

Figure 4: Alpha diversity rates in sample areas in Kargı River valley (given in order of sample area order).

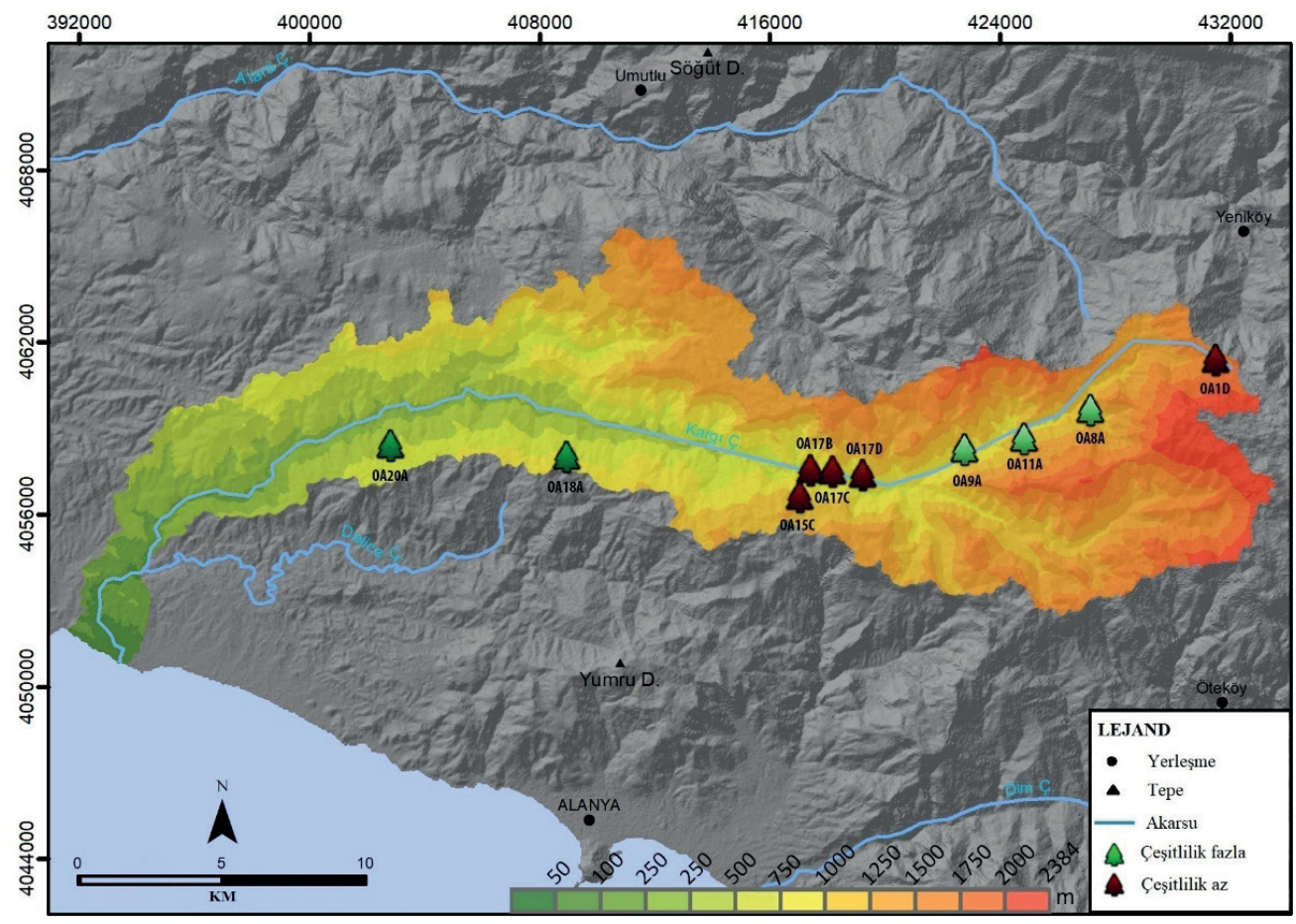

Harita 6: Kargı Çayı vadisinde alfa çeşitliliğin en yüksek ve en az olduğu örnek alanlar. Map 6: Sample areas where alpha diversity is highest and lowest in Kargı River valley. 
alandan 36 bitki taksonu kaydedilmiştir. Pinus brutia, Quercus cerris, Quercus coccifera, Olea europea var. sylvestris, Conyza canadensis, Dittrichia viscosa, Saccharum ravanae, Origanum saccatum bunlardan bazılarıdır.

ÖA20A, çoğunlukla yüksek eğimli yamaçlara sahip çayın ender durumlarda yatak derinliğinin azaldığı orta çı̆̆ırında bulunmaktadır. Akarsuya yakın yerlerde kıyı boyunca Arundo donax, Asplenium onopteris, Ceterach officinarum, Dryopteris raddeana, Piptatherum miliaceum gibi bazı otsu türler ve eğreltiler, daha geride taşkın yatağı alanında ve yamaçlarda Celtis australis, Alnus orientalis, Platanus orientalis, Nerium oleander, Arbutus andrachne, Styrax officinalis, Clematis austroanatolica gibi ağaç ve çalı türleri bulunur. $650 \mathrm{~m}$ yüksekliğe sahip bu alanda toplam 34 bitki taksonu teşhis edilmiştir.

ÖA8A, önceki alanlara nazaran akarsuyun kaynak kısmına daha yakın, 1000 m yükseklikte ana yatağa kavuşan sürekli bir yan kol üzerinde bulunmaktadır. Burada ağaç popülasyonu fazladır. 36 farklı bitki taksonu kaydedilmiştir. Fraxinus ornus, Fontanesia philliraeoides, Cnidium silaifolium, Physalis alkakengi, Plumbago europea, Solanum dulcamara bunlardan bazılarıdır. ÖA9A, yukarı çığıra yakın, $800 \mathrm{~m}$ yükseltide akarsuyun yana doğru aşındırmasının güçlü olduğu bir topografya üzerindedir. Kapatma oranının \%75 civarında olduğu saha sık bir kızılçam örtüsüyle kaplı olup karaçam bireyleri de bulunmaktadır. Datisca cannabina, Epiptactis helleborine, Inula vulgaris, Colutea cilicica, Cercis siliquastrum gibi otsu bitkiler ve çalılar yoğunluk göstermektedir. ÖA11A, akarsuyun yukarı yamacında eğimin nispeten fazla olduğu bir alandır. Burada çeşitli geofitler kaydedilmiştir. Otsuların aksine, odunsu ve çalı türleri çeşitli değildir. Alandaki 29 farklı bitki taksonunun içinde Cicer isauricum, Clinopodium vulgare subsp. arundanum, Geranium robertianum, Rubus canescens var. glabrotus yanında Fraxinus ornus subsp. cilicica ve Tilia platyphyllos gibi nemcil bitkiler de dikkat çekmektedir.

Bitki tür çeşitliliğinin en az olduğu ÖA17C, ÖA15C ile ÖA1D, Ö17B ve ÖA17D, ÖA1D hariç tamamı akarsuyun Dereköy civarına denk gelen orta çığır civarında bulunmaktadır. Bahsi geçen alanlar 700-900 m arası yükseltiye sahiptir. Yerleşme, otlatma ve hayvancılık gibi beşeri faaliyetlerin yoğunluk kazandığı bir alandır. ÖA1D ise yaklaşık 1600 m'de, akarsuyun kaynak civarındaki bozuk orman sahasındadır. Bu alanlarda en fazla 15 farklı bitki taksonu kaydedilmiştir.

Kargı Çayı'nda en yüksek evrensel beta çeşitlilik ÖA8 ile ÖA3, ÖA4, ÖA10, ÖA 20; en düşük çeşitlilik ÖA13 ile ÖA15,
ÖA, 17 ve ÖA16'dadır. Örnek alanların tamamı terra rossalar üzerindedir. ÖA8, üst çığır yakınlarında $1050 \mathrm{~m}$ yükseltide 15 $25^{\circ}$ eğime sahip kuzeybatı bakılı akarsu yatağının aşağ yamacında yer alır. Otsu bitkiler oldukça yoğun ve çeşitlidir. İki vadi içerisinde en fazla taksonun kaydedildiği yerlerdendir. ÖA4, 25-35 eğimli, 1350 m'de akarsuyun kaynak kısmı yakınlarındadır. Güneybatı bakılı bu alanda ağaç türlerinin ve çalıların çeşitliliği göze çarpar. Orman altı örtüsü Prunus divaricata, Epipactis helleborine gibi alanda çok yaygın olmayan türleri barındırır. ÖA10, 800 m'de $15-25^{\circ}$ eğimli ve kuzey bakılıdır. Üst çığır yakınlarında ripariyan örnek sahasıdır ve bu ekosisteme ait taksonu kaydedilmiştir. ÖA3, 1400 m yükseltide $25-35^{\circ}$ eğimli güneybatı bakıda bulunur. Kireçtaşı anakayası yüzeylenmiştir ve toprak derinliği oldukça azdır. Maki formasyonuna ait türlerin yanı sıra ardıç taksonu görülür. Otsu bitkiler açısından fakirdir. ÖA20, akarsu yatağ1 içinde $200 \mathrm{~m}$ yükseklikte ve $15-25^{\circ}$ eğimlidir. Dik yamaçlardaki anakaya üzerinde, çatlak sistemlerine yerleşmiş karakteristik bazı bitki türleri yayılış gösterir. Ayrıca çınar ve kızılağaç gibi taksonlar da dikkati çeker.

Düşük çeşitliliğin söz konusu olduğu alanların neredeyse tamamı akarsu vadisinin orta çı̆̆ır bölümündedir. Bunlardan ÖA13, $800 \mathrm{~m}$ yükseltide $35-45^{\circ}$ eğimli, kuzeybatı bakıya sahip kızılçam ormanında yer alır. ÖA17, 600 m'de $25-35^{\circ}$ eğimli, kuzeybatı bakılı orta yamaç konumundadır. ÖA16 ise 800 m'de $15-25^{\circ}$ eğime sahiptir. Kuzeydoğu bakılı bu alanda tahribe uğrayan maki formasyonu yer yer garig formasyonuna dönüşmüştür. ÖA15, 1000 m'de $25-35^{\circ}$ eğime sahip kuzey bakılı bir alandır. Burada da orman altı örtüsü zayıf olan bir kızılçam ormanı mevcuttur.

Sonuç olarak Kargı Çayı vadisinin kaynak ve ağız kısmına yakın alanlarda bitki çeşitliliği fazla, orta çı̆̆ırda ise azdır (Şekil 5, Harita 7). Bunun birden fazla sebebi vardır. Akarsuyun orta kesiminde yamaç dikliği fazla, bitkilerin tutunması oldukça

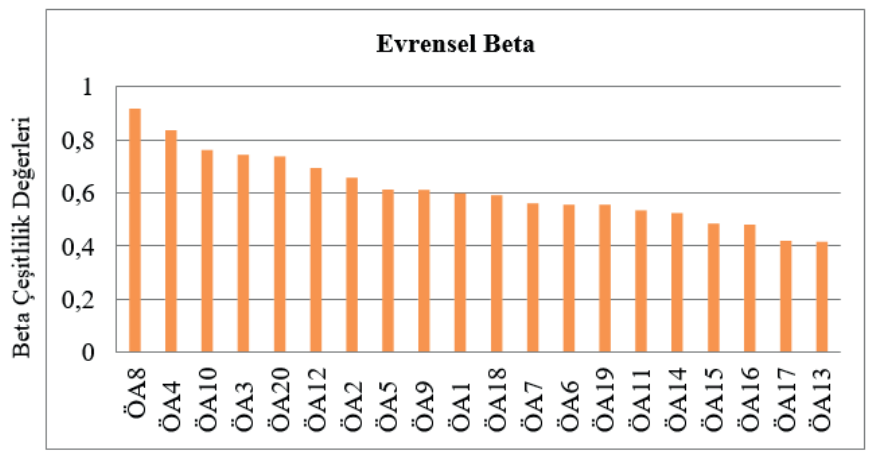

Örnek Alanlar

Şekil 5: Kargı Çayı vadisindeki örnek alanlarda beta çeşitlilik oranları (yüksek değeri içeren alandan en düşük değere doğru sıralanmıştır).

Figure 5: Beta diversity rates in the sample areas in the Kargı River valley (ranked from the highest value to the lowest value). 


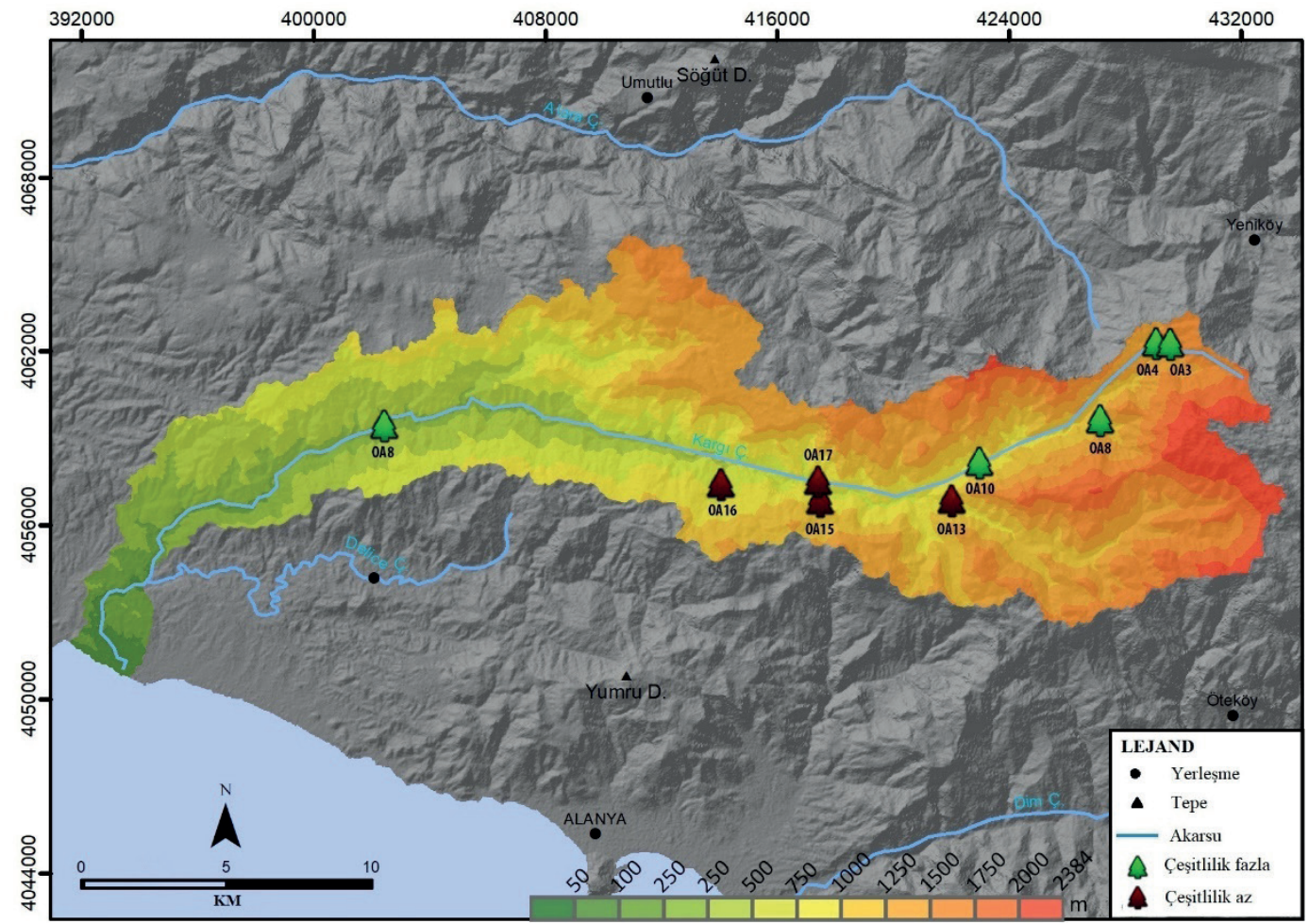

Harita 7: Kargı Çayı vadisinde beta çeşitliliğin en yüksek ve en az olduğu örnek alanlar.

Map 7: Sample areas where beta diversity is the highest and lowest in Kargı River valley.

zordur. Derin toprakların bulunduğu nispeten düzlük alanlara yoğun kızılçam ormanları yerleşmiştir. Akarsuyun yatak genişliğinin nispeten arttığı yukarı ve aşağı çığırda daha geniş alanlarda farklı bitki taksonları yerleşme imkânı bulmuştur. Bu sayede kızılçam ormanlarının yanı sıra ripariyan ekosistem türleri ve yükseltiye bağlı olarak tür değişimine uğrayan maki formasyonu gelişmiştir.

Beta çeşitlilik ölçümlerinde iki örnek alan arasında tür kompozisyonundaki süreklilik seviyesi "a" bileșeni ile ifade edilir. Bu bileşen yani a, her iki alanda da yer alan ortak türlerin toplamıdır (Koleff vd., 2003). Bu çalışmada sürekliliğin ortaya konulmasında $\boldsymbol{\beta} \boldsymbol{w}$, formülü kullanılmıştır. Özellikle tür zenginliği seviyelerinin belirgin şekilde farklı olduğu alanları karşılaştırmak için ise homojenlik özelliğinin bilinmesi gerekir (Koleff vd., 2003). Bu özelliği belirlemek için yaygın olarak $\boldsymbol{\beta} \boldsymbol{w}$ kullanılmaktadır.

Karpuz Çayı ile Kargı Çayı'nın evrensel beta çeşitlilik indisleri farklı yöntemlere göre hesaplanmıştır. Söz konusu indisler ile süreklilik, homojenlik ve kayıp-kazanç ilişkileri değerlendirilmiştir. Çeşitliliğin ölçümünde önemli bir kriter olan fenolojiyi de göz önüne alarak her iki vadiye aynı dönemde gerçekleştirilen arazi çalışmalarının değerlendirilmesiyle bu fark ortaya çıkmıştır. Biyoçeşitliliğgin ne derece fark ettiği hem örnek alanların her birine, hem de vadinin tamamına uygulanan indislerle istatistiksel olarak desteklenmektedir. Topluluklar arasındaki tür sayısının farklılığını ifade eden "toplam" yani gama $(\gamma)$ çeşitlilik, alfa ve beta çeşitlilik indis sonuçlarına göre hesaplanmaktadır. Çalışmada iki vadiye uygulanan gama çeşitlilik indisi Kargı Çayı vadisi için 4,776858, Karpuz Çayı için ise 4,49428 olarak hesaplanmıştır. Kargı Çayı'nda daha yüksek değer veren gama çeşitliliği bu vadide bitki çeşitliliğinin daha fazla olduğunu göstermektedir. Dolayısıyla bu çalışmanın esas amacı olan iki vadi arasında yapılan karşıllaştırmada öncelikli koruma alanı olarak Kargı Çayının alınabileceği ortaya çıkmaktadır.

\section{TARTIŞMA VE SONUÇ}

Türkiye 1997 y1lında Biyolojik Çeşitlilik Sözleşmesini, 2009 yılında ise Birleşmiş Milletler İklim Değişikliği Çerçeve Sözleşmesini (Kyoto Protokolü) imzalayarak biyolojik çeşitliliğini koruma yükümlülüğünü üstlenmiştir. Koruma alanlarının planlamasında sürdürülebilir politikaların geliştirilebilmesi ve uygulanabilmesi için öncelikle biyoçeşitliliğin belirlenmesi gerekmektedir. Bu amaçla belirli ölçeklerde bitki çeşitliliğinin hesaplandığı bu çalışmada alfa 
çeşitlilik (belli bir alan için çeşitliliğin ölçüsü), beta çeşitlilik (alanlar arasındaki çeşitliliğin ölçüsü) ve gama çeşitlilik (alanın toplam çeşitliliăgi) düzeyleri kullanılmıştır. Çevrelerine göre ekolojik koşullar bakımından daha farklı özelliklere sahip olmaları nedeniyle, vadiler araştırılmıştır. Resmi bir koruma statüsüne sahip olmayan Kargı Çayı vadisi ile Karpuz Çayı vadisinde toplam 160 örnek alan oluşturulmuş, 175 farklı bitki taksonu toplanmıştır. Çalışma sahasında Shannon-Wiener indisi ile alfa çeşitlilik, farklı indisler kullanılarak beta çeşitlilik hesaplanmış, bu iki vadinin biyoçeşitlilik değerleri belirlenmiştir. Elde edilen sonuçlar çeşitliliğe sebep olan çevresel faktörler açısından ele alınmıştır.

Bir alan içindeki çeşitliliğin değerlendirilmesinde $\alpha$ çeşitlilik sonuçları kullanılmaktadır. Bu amaçla Kargı çayı ile Karpuz çayı vadilerinde yapılan ölçümlerde $\boldsymbol{\alpha}$ değerinin yüksek olduğu alanlar Kargı Çayı vadisinde yerleşim alanlarına nispeten uzak olan aşağı ve yukarı çığır; Karpuz Çayı vadisinde ise yükseltinin azalmasıyla birlikte akarsu yatağının genişlediği aşağı çığırdan oluşmaktadır. Kargı Çayı'nın kuzeydoğusundaki alfa çeşitliliğin yüksek olduğu alanlar; düze yakın topografyada gelişen kızılçam ormanları ile eğim derecesinin arttığı akarsu vadisinin alt ve orta yamaçlarındaki su talebi yüksek bitki taksonlarının bulunduğu geçiş bölgeleridir. Güneybatıdaki yüksek alfa değeri veren örnek alanlarda da durum benzerdir. Buralardaki artışın sebebi ise kızılçam topluluklarıyla maki sahalarının ve riparyan ortamların iç içe geçmiş olmasıdır. Karpuz Çayı'nda alfa çeşitliliğin yüksek olduğu alanlar topografik olarak bitki yetişmesine elverişli, farklı ekolojik ortamlar barındıran (ormanlık alanlar, makilikler ve akarsu yatağında debinin düştüğü kesimlerdeki alüvyal birikintiler üzerinde yetişen sucul bitkiler) ve beşeri faaliyetlere nispeten uzak sahalardır. Kuzeyde alfa çeşitliliğin az olduğu örnek alanların bazılarında eğim fazladır ve toprağın üst katmanları çoğu yerde vadi içlerine doğru süpürülmüştür. Ayrıca akarsuyun bu kısmı beşeri faaliyetlerin yoğunluk kazandı ğ1 sahalara ve ulaşım yollarına yakınlı̆̆ 1 sebebiyle çokça tahrip edilmiştir.

$\boldsymbol{\beta}$ çeşitlilik, alanlar arasındaki süreklilik, homojenlik ve kayıp-kazanç ilişkilerini belirlemek için kullanılmaktadır. Yapılan çalışmalarda yaygın olarak kullanılan $\boldsymbol{\beta} \boldsymbol{w}$ hem süreklilik hem de homojenliği göstermektedir. Kargı çayı Karpuz çayına nazaran daha düşük sürekliliğe sahiptir. Yani her iki saha arasında yer alan ortak bitki taksonları bakımından değerlendirildiğinde Kargı Çayı vadisinde bu değer daha düşüktür. Kargı Çayı vadisi aynı zamanda daha az homojenliğe de sahiptir. Başka kelimelerle Kargı çayı vadisinde örnek alanlar arasında ortak bitki taksonları, Karpuz çayına nazaran daha azdır. Bu durum aynı zamanda Kargı çayı vadisinin Karpuz çayı vadisine nazaran daha az homojen olduğunu göstermektedir. Bu analizin genel olarak değerlendirmesi Kargı Çayı vadisinin, Karpuz Çayı vadisine oranla daha yüksek beta çeşitliliğe sahip olduğunu göstermektedir. Bu durum Kargı Çayı'nın Karpuz Çayı'na nazaran daha çeşitli yetişme ortamı özelliklerine sahip olmasından ileri gelmektedir. İki akarsu uzunluk bakımından benzer olsa da uzanış doğrultuları sebebiyle farklıdır. Karpuz Çayı yatağı kabaca KD-GB yönünde neredeyse düz bir hat boyunca uzanır. Akarsuyun güneyinde yamaçların ortalama eğimi $0-16^{\circ}$, kuzeyde ise $27-48^{\circ}$ dir Akarsuyun uzanış doğrultusu sebebiyle yamaçlar genelde doğu ve batı bakıdadır. Kargı Çayı'nda durum nispeten farklıdır. Ağıza yakın kesimi kuzey-güney doğrultusundayken, kuzeye gidildikçe doğu-batı yönüne döner. Akarsuyun yamaçları çoğunlukla kuzey ve güney bakıdadır. Özellikle güneşlenme süresi ve yağış açısından farklılık gösteren yetişme ortamlarının bulunuşu bitki çeşitliliğini artırmıştır. Yatak boyunca alt ve orta yamaçlarda ortalama eğim derecesi $16-27^{\circ}$ 'dir. Buralar vadinin bitki tür çeşitliliği açısından en zengin kesimleridir. Üst yamaçlarında eğimin $15^{\circ}$ ye kadar düzleştiği alanlar ise yoğun kızılçam ormanlarıyla kaplı olup, orman altı örtüsü nispeten fakirdir.

Alanın toplam çeşitliliğini ifade eden ve iki vadiye uygulanan $\gamma$ çeşitlilik arazi çalışmaları esnasında yapılan gözlemleri destekler niteliktedir. Gama çeşitliliği sonucuna göre Kargı Çayı vadisi Karpuz Çayı vadisinde oranla daha fazla bitki çeşitliliğine sahiptir. Alfa ve beta çeşitlilikte de bitki taksonlarının Karpuz Çayı'na oranla daha heterojen dağıldığı ve süreklilik oranlarının daha düşük olduğu Kargı Çayı, üç çeşitlilik indisine göre de korumada öncelikli alan olarak belirmektedir.

Beşeri faaliyetlerin baskıladığı alanlar gün geçtikçe artsa da, sahip olduğu ekolojik koşullar ve bitki çeşitliliği nedeniyle sürdürülebilir, uygulaması kolay ve etkin statüler ile korunmaya değer alanlar halen oldukça fazladır. Bu çalışmanın yapıldığı alan örneğinde görüldüğü gibi belirli sahalarda biyoçeşitliliğinin tespiti, sonrasında muhafaza edilmesi, tür kaybı ve habitat parçalanması gibi olumsuzlukların ortadan kaldırılması için temel adımı oluşturmaktadır. Yapılacak çalışmalar ile beşeri etkilerin alanları sınırlandırılarak, biyoçeşitlilik kaybı en aza indirilebilecektir. Alfa, beta ve gama çeşitlilik indisi gibi yöntemler kullanılarak koruma alanlarının belirlenmesinde çeşitli çıkarımlarda bulunmak mümkün olmaktadır. Dolayısıyla bu gibi çalışmaların yaygınlaşması korumada öncelik verilmesi gereken alanların kararlaştırmasında karar mercilerine yol göstermek açısından büyük önem taşımaktadır. 
Hakem Değerlendirmesi: Dış bağımsız.

Çıkar Çatışması: Yazarlar çıkar çatışması bildirmemiştir.

Finansal Destek: Yazarlar bu çalışma için finansal destek almadığını beyan etmiştir.

Teşekkür: Bu çalışmada kullanılan biyolojik çeşitlilik ölçümleri doktora tezi kapsamında Öğr. Gör. Dr. Seda Akkurt Gümüş tarafından gerçekleştirilmiştir. Yazarlar TÜBİTAK 2237A "Biyolojik Çeşitlilik Ölçüm Süreçleri-Envanter, Veri Transferi ve Hesaplama Teknikleri" adlı bilimsel etkinliği düzenleyen Prof. Dr. Kürşad Özkan'a ve etkinliğe mali destek olan TÜBITTAK'a, bitki teşhisleri konusundaki yardımları için Dr. Münevver Arslan'a, arazi çalışmalarındaki yardımlarından dolayı Dr. Öğrt. Üyesi Erdal Gümüş’e ve Arş. Gör. Emirhan Berberoğlu'na, yapıcı eleştirilerinden dolayı hakemlere teşekkür ederler.

Peer-review: Externally peer-reviewed.

Conflict of Interest: The authors have no conflict of interest to declare.

Grant Support: The authors declared that this study has received no financial support.

Acknowledgement: Biodiversity measurements used in this study were carried out by Dr. Seda Akkurt Gümüş in her doctoral dissertation. The authors admit special thanks to TÜBITTAK for the financial support and Prof. Kürşad Özkan for organizing the "2237-A Biological Diversity Measurement Processes-Inventory, Data Transfer and Computing Techniques" scientific event. Last but not least, many thanks to Dr. Münevver Arslan for taxonomic diagnosis, to Dr. Erdal Gümüş and RA Emirhan Berberoğlu for their assistance in field studies, and finally to the reviewers for their constructive criticism.

\section{KAYNAKÇA/REFERENCES}

Anderson, M. J., Crist, T. O., Freestone, A. L. \& Sanders, N. J. (2011). Navigating the multiple meanings of $\beta$-diversity: a roadmap for the practising ecologist. Ecology Letters, 14, 19-28.

Avcı, M. (2018). Ekosistem Coğrafyası, İstanbul Üniversitesi Açık ve Uzaktan Eğitim Fakültesi, Coğrafya Lisans Program1, İstanbul.

Boulos, L., Miller, A. G. \& Mill, R. R. (1994). Regional overview South West Asia and the Middle East. Centers of Plant Diversity I (Ed. S.D. Davis, V.H. Heywood and A.C. Hamilton), WWF and IUCN, U.K., 293-308.

Buckley, L. B. \& Jetz, W. (2007). Environmental and historical constraints on global patterns of amphibian richness. Proceedings Biological Science/The Royal Society, 274, 1167-1173.

Cayuela, L., Benayas, J. M. R., Justel, A. \& Salas-Rey, J. (2006). Modelling tree diversity in a highly fragmented tropical montane landscape. Global Ecology and Biogeography, 15(6), 602-613.

Cody, M. L. (1975). Towards a theory of continental species diversities: bird distributions over mediterranean habitat gradients, Ecology and Evolution of Communities, (Ed: Cody, M.L. \& Diamond, J.M.), Belknap Press, Cambridge, Massachusetts, 214-275.

Condit, R., Pitman, N., Egbert, G., Leigh, J., Chave, J., Terborgh, J., Foster, R., Nunez, V., Aguilar, V., Valencia, R., Villa, G., MullerLandau, H., Losos, E. \& Hubbel, H. (2002). Beta- diversity in Tropical forest trees. Science, 295, 666-669.

Davis, P. H. (1965-1985). Flora of Turkey and the East Aegean Islands. Edinburgh University Press, Vol: 1-9, Edinburgh.

Davis, P. H., Mill, R. R., Tan, K., (1998). Flora of Turkey and the East Aegean Islands (Supplement 1). Edinburgh University Press, Vol: 10, Edinburgh.

Duman, H. (2005). Kargı Çayı vadisi, Türkiye'nin 122 Önemli Bitki Alanı, (Ed: N. Özhatay, A. Byfield, S. Atay), WWF Türkiye (Doğal Hayatı Koruma Vakfi) Yayını, İstanbul, 231-232.
Fortin, M. \& Dale, M. R. T. (2005). Spatial Analysis: A Guide for Ecologists, Cambridge University Press.

Gaston, K. J. (2010). Biodiversity, Conservation Biology for All (Ed. Sodhi, N.S. ve Ehrlich, P.R.). Oxford University Press Inc., New York.

Groombridge, B. \& Jenkins, M. D. (2002). World Atlas of Biodiversity. UNEP, University of California Press, USA.

Gueze, M., Paneque-Galvez, C., Luz, A.C., Pino, J., Orto-Martines, M., Reyes-Garcia, V. \& Manuel, J. (2013). Determinants of tree species turnover in southern Amazonian rain forest. Journal of Vegetation Science, 24, 284-295.

Gülsoy, S. \& Özkan, K. (2008). Tür çeşitliliğinin ekolojik açıdan önemi ve kullanılan bazı indisler. Süleyman Demirel Üniversitesi Orman Fakültesi Dergisi, A(1): 168-178.

Güner, A., Özhatay, N., Ekim, T. \& Başer, K. H. C. (2000). Flora of Turkey and the East Aegean Islands (Supplement 2). Edinburgh University Press, Vol: 11, Edinburgh.

Harrison, S., Ross, S. J. \& Lawton, J. H. (1992). Beta diversity on geographic gradients in Britain. Journal of Animal Ecology, 61(1), 151-158.

Hui, C. (2015). Unlocking Patterns of Nature- The Marriage of Mathematics and Ecology, Sun Media Press.

Jost, L. (2007). Partitioning diversity into independent alpha and beta components. Ecology, 88(10), 2427-2439.

Jurasinski, G., Retzer, V. \& Beierkuhnlein, C. (2009). Inventory, differentiation, and proportional diversity: a consistent terminology for quantifying species diversity. Oecologia, 159, 15-26.

Keil, P., Schweiger, O., Kühn, I., Kunin, W. E., Kuussaari, M., Settele, J., Henle, K., Brotons, L., Pe'er, G., Lengyel, S., Moustakas, A., Steinicke, H. \& Storch, D. (2012). Patterns of beta diversity in Europe: the role of climate, land cover and distance across scales. Journal of Biogeography, 39, 1473-1486.

Koleff, P., Gaston, K. J. \& Lennon, J. J. (2003). Measuring beta diversity for presence-absence data. Journal of Animal Ecology, 72, 367-382.

Legendre, P., Borcard, D. \& Peres-Neto, P. P. (2005). Analyzing beta diversity: partitioning the spatial variation of community composition data. Ecological Monographs, 75(4), 435-450.

Legendre, P., Mi, X., Ren, H., Ma, K., Yu, M., Sun, I.F. \& He, F. (2009). Partitioning beta diversity in a subtropical broad-leaved forest in China. Ecology, 90, 663-674.

Loreau, M. (2000). Are communities saturated? on the relationship between $\alpha, \beta$ and $\gamma$ diversity. Ecology Letters, 3(2), 73-76.

MacArthur, R. H. (1965). Patterns of species diversity. Biological Reviews, 40, 510-533.

Magurran, A. E. (2005). Species abundance distributions pattern or process?. Functional Ecology, 19(1), 177-181.

Mora, C., Tittensor, D. P., Adl, S., Simpson, A. G. B. \& Worm, B. (2011). How many species are there on earth and in the ocean? PLoS Biology, 9(8): e1001127. https://doi.org/10.1371/journal. pbio. 1001127.

Negiz, M. G. (2013). Gölhisar (Burdur) Yöresinde Odunsu Tür Çeşitliliği ile Yetişme Ortamı Özellikleri Arasındaki İlişkiler, Süleyman Demirel Üniversitesi, Fen Bilimleri Enstitüsü, Doktora Tezi. 
Negiz, M. G. \& Özkan, K. (2016). The relationships between beta plant diversity and climatic variables: a case study in Kuyucak mountain district. GEOMED 2016 Bildiri Özetleri Kitabı, 218.

Neilan, W. L., Barton, P. S., McAlpine, C. A., Wood, J. T. \& Lindenmayer, D. B. (2019). Contrasting effects of mosaic structure on alpha and beta diversity of bird assemblages in a human-modified landscape. Ecography, 42(1), 173-186.

Nekola, J. C. \& White, P. S. (1999). The distance decay of similarity in biogeography and ecology, Journal of Biogeography, 26(4), 867878.

Özkan, K. (2010). Orman ekosistem çeşitliliği haritalama çalışmaları için ekolojik alan çeşitliliğinin belirlenmesi üzerine bir öneri. Süleyman Demirel Üniversitesi Orman Fakültesi Dergisi, A(2), $136-148$

Özkan, K. (2016), Biyolojik Çeşitlilik Bileşenleri ( $\alpha, \beta$ ve $\gamma$ ) Nasıl Ölçülür, Süleyman Demirel Üniversitesi Yayınevi, Isparta.

Pimm, S. L. \& Gittleman, J. L. (1992). Biological diversity: where is it?. Science, 255(5047), 940.

Pinto-Ledezma, J. N., Larkin, D. J. \& Cavender-Bares, J. (2018). Patterns of beta diversity of vascular plants and their correspondence with biome boundaries across North America. Frontiers in Ecology and Evolution, 1-13.

Socolar, J. B., Gilroy, J. J., Kunin, W. E. \& Edwards, D. P. (2016). How should beta-diversity inform biodiversity conservation?. Trends in Ecology \& Evolution, 31(1), 67-80.

Tuomisto, H. (2010a). A diversity of beta diversities: straightening up a concept gone awry. Part 1. Defining beta diversity as a function of alpha and gamma diversity, Ecography, 33(1), 2-22.
Tuomisto, H. (2010b). A diversity of beta diversities: straightening up a concept gone awry. Part 2. Quantifying beta diversity and related phenomena. Ecography, 33, 23-45.

Veech, J. A. \& Crist, T. O. (2007). Diversity partitioning without statistical independence of alpha and beta. Ecology, 91(7), 19641969.

Volkov, I., Banavar, J. R., Hubbell, S. P. \& Maritan, A. (2003). Neutral theory and relative species abundance in ecology. Nature, 424, 1035-1037.

Wang, Z., Fang, J., Tang, Z. \& Shi, L. (2012). Geographical patterns in the beta diversity of China's woody plants: the influence of space, environment and range size. Ecography, 35, 1092-1102.

Westhoff, V. \& Maarel, E. van der (1980). The Braun-Blanquet Approach. Classification of Plants Communities (Ed. R.J. Whittaker): 287-399. The Haque: Dr. W. Junk bv Publishers.

Whittaker, R. H. (1960). Vegetation of the Siskiyou mountains, Oregon and California. Ecological Monographs, 30, 279-338.

Whittaker, R. H. (1972). Evolution and measurement of species diversity. Taxon, 21, 213-251.

Wilson, M. V. \& Shmida, A. (1984). Measuring beta diversity with presence-absence data. Journal of Ecology, 72, 1055-1064.

Zhang, Q., Hou X., Li F.Y., Niu J., Zhou Y., Ding Y. (2014). Alpha, beta and gamma diversity differ in response to precipitation in the inner Mongolia grassland. Plos One, 9(3), 1-9. 


\section{MAKALE EKİ}

\begin{tabular}{|c|c|c|c|c|c|c|c|}
\hline \multicolumn{4}{|c|}{ KARPUZ ÇAYI } & \multicolumn{4}{|c|}{ KARGI ÇAYI } \\
\hline Örnek Alan & Shannon_H & Evrensel Beta & Tür Sayısı & Örnek Alan & Shannon_H & Evrensel Beta & Tür Sayısı \\
\hline $01 \mathrm{~A}$ & 3,03 & \multirow{4}{*}{0,6667} & 25 & $01 \mathrm{~A}$ & 2,555 & \multirow{4}{*}{0,60000} & 14 \\
\hline O1B & 2,45 & & 13 & $\mathrm{O} 1 \mathrm{~B}$ & 1,871 & & 8 \\
\hline $\mathrm{O} 1 \mathrm{C}$ & 2,37 & & 12 & O1C & 2,013 & & 8 \\
\hline O1D & 2,16 & & 11 & O1D & 1,762 & & 6 \\
\hline $\mathrm{O} 2 \mathrm{~A}$ & 2,89 & \multirow{4}{*}{0,4035} & 20 & $\mathrm{O} 2 \mathrm{~A}$ & 2,751 & \multirow{4}{*}{0,65854} & 16 \\
\hline $\mathrm{O} 2 \mathrm{~B}$ & 2,42 & & 13 & $\mathrm{O} 2 \mathrm{~B}$ & 1,925 & & 8 \\
\hline $\mathrm{O} 2 \mathrm{C}$ & 2,41 & & 12 & $\mathrm{O} 2 \mathrm{C}$ & 2,287 & & 10 \\
\hline $\mathrm{O} 2 \mathrm{D}$ & 2,46 & & 13 & $\mathrm{O} 2 \mathrm{D}$ & 2,007 & & 8 \\
\hline $\mathrm{O} 3 \mathrm{~A}$ & 3,38 & \multirow{4}{*}{0,8592} & 32 & $\mathrm{O} 3 \mathrm{~A}$ & 2,688 & \multirow{4}{*}{0,74359} & 16 \\
\hline $\mathrm{O} 3 \mathrm{~B}$ & 2,74 & & 16 & $\mathrm{O} 3 \mathrm{~B}$ & 2,172 & & 10 \\
\hline $\mathrm{O} 3 \mathrm{C}$ & 2,37 & & 11 & $\mathrm{O} 3 \mathrm{C}$ & 1,848 & & 7 \\
\hline O3D & 2,45 & & 12 & O3D & 1,862 & & 7 \\
\hline O4A & 2,84 & \multirow{4}{*}{0,6667} & 19 & O4A & 2,564 & \multirow{4}{*}{0,83784} & 15 \\
\hline O4B & 2,26 & & 11 & O4B & 2,062 & & 8 \\
\hline $\mathrm{O} 4 \mathrm{C}$ & 2,13 & & 9 & $\mathrm{O} 4 \mathrm{C}$ & 1,997 & & 8 \\
\hline O4D & 2,21 & & 11 & O4D & 1,931 & & 7 \\
\hline O5A & 2,57 & \multirow{4}{*}{0,6667} & 25 & O5A & 3,149 & \multirow{4}{*}{0,61290} & 25 \\
\hline O5B & 3,13 & & 15 & O5B & 2,619 & & 15 \\
\hline O5C & 2,30 & & 11 & O5C & 2,681 & & 15 \\
\hline O5D & 2,22 & & 10 & O5D & 2,167 & & 11 \\
\hline O6A & 2,18 & \multirow{4}{*}{0,7561} & 18 & O6A & 2,934 & \multirow{4}{*}{0,55556} & 21 \\
\hline O6B & 2,29 & & 11 & O6B & 2,354 & & 12 \\
\hline $\mathrm{O} 6 \mathrm{C}$ & 2,07 & & 8 & O6C & 2,376 & & 12 \\
\hline O6D & 2,62 & & 9 & O6D & 2,11 & & 9 \\
\hline O7A & 2,33 & \multirow{4}{*}{0,6000} & 14 & O7A & 2,598 & \multirow{4}{*}{0,56098} & 15 \\
\hline O7B & 1,82 & & 7 & O7B & 2,142 & & 9 \\
\hline O7C & 2,00 & & 8 & O7C & 2,092 & & 9 \\
\hline O7D & 1,98 & & 9 & O7D & 2,059 & & 8 \\
\hline $\mathrm{O} 8 \mathrm{~A}$ & 2,39 & \multirow{4}{*}{0,6000} & 18 & $\mathrm{O} 8 \mathrm{~A}$ & 3,311 & \multirow{4}{*}{0,91781} & 35 \\
\hline O8B & 2,58 & & 12 & $\mathrm{O} 8 \mathrm{~B}$ & 2,681 & & 16 \\
\hline $\mathrm{O} 8 \mathrm{C}$ & 1,98 & & 8 & $\mathrm{O} 8 \mathrm{C}$ & 2,618 & & 15 \\
\hline O8D & 2,22 & & 10 & O8D & 2,295 & & 11 \\
\hline O9A & 2,60 & & 17 & O9A & 3,29 & & 29 \\
\hline O9B & 2,26 & 05000 & 9 & O9B & 2,773 & 061111 & 17 \\
\hline O9C & 2,40 & 0,5000 & 12 & O9C & 2,481 & 0,61111 & 13 \\
\hline O9D & 2,33 & & 11 & O9D & 2,506 & & 13 \\
\hline O10A & 2,41 & & 14 & O10A & 3,062 & & 24 \\
\hline O10B & 2,12 & 05556 & 8 & O10B & 2,528 & 076271 & 14 \\
\hline O10C & 1,97 & 0,5556 & 8 & O10C & 2,209 & $0, / 62 / 1$ & 10 \\
\hline O10D & 1,90 & & 7 & O10D & 2,2 & & 13 \\
\hline $011 \mathrm{~A}$ & 2,30 & & 16 & $011 \mathrm{~A}$ & 3,181 & & 28 \\
\hline O11B & 2,31 & (2707 & 10 & 011B & 2,704 & 053425 & 17 \\
\hline $011 \mathrm{C}$ & 1,98 & $0, / 291$ & 9 & $011 \mathrm{C}$ & 2,464 & 0,53425 & 13 \\
\hline O11D & 1,87 & & 8 & O11D & 2,593 & & 15 \\
\hline O12A & 2,70 & & 23 & $012 \mathrm{~A}$ & 3,096 & & 24 \\
\hline O12B & 2,66 & 0.5714 & 12 & O12B & 2,478 & 069492 & 13 \\
\hline $012 \mathrm{C}$ & 2,26 & $0,5 / 14$ & 10 & $\mathrm{O} 12 \mathrm{C}$ & 2,451 & 0,69492 & 12 \\
\hline O12D & 2,35 & & 10 & O12D & 2,109 & & 9 \\
\hline 013A & 2,69 & & 20 & 013A & 2,647 & & 16 \\
\hline O13B & 2,55 & 05001 & 13 & O13B & 2,396 & 091667 & 12 \\
\hline O13C & 2,39 & 0,5094 & 11 & O13C & 2,133 & $0,4166 /$ & 9 \\
\hline O13D & 2,32 & & 7 & O13D & 2,335 & & 12 \\
\hline
\end{tabular}




\begin{tabular}{|c|c|c|c|c|c|c|c|}
\hline O14A & 2,91 & \multirow{4}{*}{0,9672} & 27 & O14A & 3,092 & \multirow{4}{*}{0,52381} & 24 \\
\hline O14B & 2,47 & & 12 & O14B & 2,549 & & 14 \\
\hline O14C & 2,71 & & 17 & O14C & 2,097 & & 9 \\
\hline O14D & 2,44 & & 12 & O14D & 2,707 & & 16 \\
\hline O15A & 2,47 & \multirow{4}{*}{0,5814} & 18 & $015 \mathrm{~A}$ & 2,38 & \multirow{4}{*}{0,48571} & 13 \\
\hline O15B & 2,22 & & 10 & O15B & 1,954 & & 8 \\
\hline O15C & 2,00 & & 10 & O15C & 1,712 & & 6 \\
\hline O15D & 2,43 & & 12 & O15D & 1,982 & & 8 \\
\hline O16A & 2,60 & \multirow{4}{*}{0,6471} & 21 & O16A & 2,781 & \multirow{4}{*}{0,48148} & 19 \\
\hline O16B & 2,54 & & 14 & O16B & 2,367 & & 12 \\
\hline O16C & 2,40 & & 11 & $\mathrm{O} 16 \mathrm{C}$ & 2,182 & & 10 \\
\hline O16D & 2,23 & & 10 & O16D & 2,463 & & 13 \\
\hline O17A & 2,69 & \multirow{4}{*}{0,7143} & 25 & O17A & 2,228 & \multirow{4}{*}{0,41935} & 11 \\
\hline O17B & 2,62 & & 14 & O17B & 1,791 & & 7 \\
\hline O17C & 2,46 & & 13 & O17C & 1,644 & & 6 \\
\hline O17D & 2,38 & & 13 & O17D & 1,818 & & 7 \\
\hline O18A & 2,51 & \multirow{4}{*}{0,7391} & 20 & O18A & 3,519 & \multirow{3}{*}{0,59091} & 36 \\
\hline O18B & 2,13 & & 9 & O18B & 2,957 & & 20 \\
\hline $\mathrm{O} 18 \mathrm{C}$ & 2,22 & & 8 & O18C & 2,646 & & 15 \\
\hline O18D & 2,49 & & 8 & O18D & 2,855 & & 19 \\
\hline O19A & 2,38 & \multirow{4}{*}{0,6585} & 14 & O19A & 2,976 & \multirow{4}{*}{0,55556} & 21 \\
\hline O19B & 2,27 & & 8 & O19B & 2,237 & & 10 \\
\hline O19C & 2,10 & & 8 & O19C & 2,493 & & 13 \\
\hline O19D & 1,94 & & 8 & O19D & 2,188 & & 10 \\
\hline O20A & 2,23 & \multirow{4}{*}{0,6216} & 14 & O20A & 3,477 & \multirow{4}{*}{0,73684} & 33 \\
\hline O20B & 2,03 & & 8 & O20B & 2,976 & & 20 \\
\hline O20C & 1,95 & & 8 & O20C & 2,465 & & 12 \\
\hline O20D & 2,04 & & 9 & O20D & 2,358 & & 12 \\
\hline
\end{tabular}

